\title{
Bektaşilik ve İstanbul'daki Bektaşi Tekkeleri Üzerine Bir İnceleme
}

Gülay Yılmaz*

A Study on Bektashi Order and Bektashi Lodges in Istanbul

Abstract This article examines the Bektashi lodges in Istanbul from the time the city was conquered to the times that the lodges were closed/transformed/or put under a more strict control after the abolition of the janissary army in 1826 . The goal of this study is to investigate the history of the Bektashi lodges in Istanbul with reference to the institutionalization of Bektashism in general and of the Janissary army and to provide a contextual analysis of their history. We argue that the Bektashi sect, reorganized during the reign of Bayezid II, underwent an institutionalization similar to that of other Istanbul lodges. The second juncture of the history of the Bektashi lodges in Istanbul is the second half of the 18th century. This new phase in the history of the logdes was cut off with the 1826 intervention of the state.

Keywords: Bektashi Order, Lodge, Istanbul, Bayezid II, Janissary Army, Waqf Deeds, Karaağaç, Erikli Baba, Perişan Baba, Şehidlik, Durmuş Dede, Şahkulu Sultan, Karaca Ahmed Sultan, Yarımca Baba, Mürüvvet Baba, Karyağdı Baba, Kıncı Baba, Tahir Baba, Conquest of Istanbul

Osmanlı döneminde İstanbul'daki Bektaşi tekkeleri ve özellikle bunların toplumla ve Yeniçeri Ocağı ile olan ilişkilerinin ne olduğu sorusu, son derece ilgi çeken fakat araştırması arşiv kaynaklarının yetersizliği dolayısıyla sıkıntılı bir konu olmuştur. Zira İstanbul'da ve hatta Osmanlı'nın diğer coğrafyalarındaki tekkeler hakkındaki arşiv belgeleri daha çok 19. yüzyıla, özellikle de Yeniçeri Ocağı’nın kaldırılışı

* Akdeniz Üniversitesi. 
esnasında kapatılmalarına dair yapılmış muamelelere yoğunlaşmıştır. Bazı Bektaşi tekke ve zaviyelerinin İstanbul'da mevcudiyetlerini -belki bir belgede isminin zikrinden, belki hala mevcut olan kabristanlarındaki mezar taşlarından- mutlak surette bildiğimiz halde 19. yüzyıldan önceki faaliyetlerine dair belgelere arşivlerde pek rastlayamamaktayız. Bu belge darlığının da etkisiyle bu alanda yapılmış birçok çalışma, mezar taşlarını da analiz ederek bu bilinmeyen tarihi aydınlatmaya çalışmıştır.

Elinizdeki çalışma arşivlerde yapılmış yoğun araştırmaların sonucunda bulunabilmiş belgeler ekseninde İstanbul'daki Bektaşi tekkelerini tespit etmiş ve nasıl bir yapılanma içerisinde olduklarını anlamayı hedeflemiştir. Makale, özellikle, II. Bayezid döneminde hem edep erkân hususunda, hem de devlet yönetimi altında bir teşkilatlanmaya giden Bektaşiliğin, İstanbul'da benzer şekilde bir kurumsallaşma sürecinden geçtiğini ileri sürmektedir. Dahası bu kurumsallaşma sürecinde Yeniçeri Ocağı ile bir entegrasyona gidildiğini de göstermek amacındadır. Bu dönem içerisinde Karaağaç, Şehidlik ve Mehmet Efendi gibi kadim Bektaşi tekkeleri İstanbul'da faaliyet göstermeye başlamışlardır. II. Bayezid döneminde başlayan ve 17. yüzyıla kadar uzanan bu sürecin 18. yüzyılın ikinci yarısında farklı bir evreye girdiğini ve bunun da 1826'ya kadar devam ettiğini düşünmekteyiz. Bunun sebebi, İstanbul içinde önemli kabul ettiğimiz bazı Bektaşi tekkelerinin 1826'dan önceki yaklaşık elli yıllık dönem içerisinde kurulmuş olduğudur.

Bektaşi tekkelerinin 1826'daki devlet müdahalesi ile nasıl başa çıktığına dair birkaçönemli bilgiye değinmekle beraber makalenin yoğunlaştığı dönem aralığı II. Bayezid döneminden 1826'ya kadar ki süreçtir. Bu kadar kısıtlı arşiv malzemesinin olduğu bir alanda tespit edilen her belge bir kiymet arz etmekte olduğundan bu makale, İstanbul'daki tüm Bektaşi tekke ve zaviyeleri ile ilgili belge ve bilgileri düzenli bir şekilde sunmayı amaçlamaktadır. Bununla beraber makalenin İstanbul Bektaşiliğine dair tamamlanmış bir çalışma olmayıp mevcut literatüre ek bilgi ve belgeler sunan bir katkı olduğunu söylememiz gerekir.

\section{Bektaşiliğin Kısa Tarihçesi}

Bektaşiliğin tarihçesinin 13. yüzyıldan başladığı kabul edilmektedir. Gelişimi ise iki evreden oluşmuştur. Birinci devre 13. yüzyılda başlayıp 15. yüzyılın sonlarına kadar süren oluşum devresidir. İkinci devre 16. yüzyılda Balım Sultan ile başlayan resmen kuruluş ve kurumlaşma dönemidir. Bektaşilik bugün anladığımız anlamdaki formuna bu dönemde yaklaşmış, kurumsal yapılanmaya girmiştir. Bu ikinci evrede ise 1826 da Yeniçeri Ocağı'nın kapatılması esnasında büyük darbe 
yiyen ve hatta kapatılan Bektaşi tekkelerinin 1925'te Türkiye Cumhuriyeti'nin tekke ve zaviyeleri topyekûn yasaklayan kanununa kadar ki süreci tekrar canlanma dönemi olarak ayrı bir değerlendirmeye tabii tutmak gerekir.

Bektaşiliğin 13. yüzyılda oluştuğu ve ilk Bektaşi babalarının müritlerinin Türkmen ve Moğol göçebeleri arasında bulunduğu bilinmektedir. Orta Asya Türkleri ile olan bu bağlantı Anadolu'nun İslâmlaşması dönemindeki diğer evliyalar gibi Bektaşi evliyasını da İslâm-Türk heterodoksisinin önemli bir damarı haline getirmiştir. ${ }^{1}$ İlk dönem Bektaşilerinin Babai isyanı ile yakından ilişkili olduğu artık günümüzde kabul görmüş bir görüştür. Babai hareketinin 14. yüzyıldaki devamı olan Rum Abdalları ilk Osmanlı beylerinin yaptırdıkları zaviyelerinde birçok mürit yetiştirmiştir ki bunlar sonradan Bektaşiler tarafından tarikatın ilk kurucuları olarak kabul edilmiştir. ${ }^{2}$

İlk dönem Bektaşi dervişlerinin birer kolonizatör gibi faaliyet gösterip Osmanlı sultanlarının iskâna açtıkları Balkan topraklarında zaviyeler kurup yeni fethedilmiş bölgelerin Türkleşmesi ve İslâmlaşması için faaliyette bulundukları, Barkan’ın değerli çalışmaları sayesinde saptanmıştır. ${ }^{3}$ Bu Bektaşilerin kimler olduğu, ne tür ilişkiler içerisinde bulunduğu sorusunun peşinden giden diğer araştırmacılar Balkanlara ilk yerleşmiş bazı Bektaşiler üzerine çalışmıştır. ${ }^{4}$ Daha sonraki yüzyıllarda Anadolu’dan Mısır ve Irak gibi bölgelere giden dervişlerin Bektaşiliği yaygınlaştırdığı araştırmalarla sabittir. Fuad Köprülü, Anadolu ile özellikle de Antalya ve Alaiye gibi önemli ticari merkezlerle yoğun temasta olan Misır'da, Bektaşiliğin 15. yüzyılın ilk senelerinde yerleşmiş olabileceğini belirtmiştir. Bu yerleşme

1 Fuat Köprülü, Türk Edebiyatında İlk Mutasavvıflar (Ankara: Diyanet İşleri Başkanlığı Yayınları, 1966), s. 6-25.

2 Ahmet Yaşar Ocak, Babailer Isyanı: Aleviliğin Tarihsel Altyapısı, Anadolu'da İslam-Türk Heterodoksisinin Teşekkülü (İstanbul: Dergah Yayınları, 2000), s. 215-17.

3 Ömer L. Barkan, "Osmanlı İmparatorluğunda Bir İskan ve Kolonizasyon Metodu Olarak Vakıflar ve Temlikler," Vakıflar Dergisi 5 (1942), s. 279-386.

4 İrène Beldiceanu-Steinherr, "La Vita de Seyyid 'Ali Sultan et la conquête de la Thrace par les Turcs," Proceedings of the Twenty-Seventh International Congress par les Orientalists (Michigan, Ann Arbor, 13-19 Ağustos 1967), s. 275-76; Ahmet Yaşar Ocak, "Emirci Sultan ve Zaviyesi," Tarih Enstitüsü Dergisi 9 (1978), s. 129-208; Rıza Yıldırım, "Dervishes, Waqfs and Conquest: Notes on Early Ottoman Expansion in Thrace," der. Pascale Ghazaleh, Held in Trust: Waqf in the Islamic World içinde (Kahire: Amerikan Üniversitesi Yayınları, 2011), s. 23-40; Rıza Yıldırım, "Bektaşi-Alevi Geleneğine Göre Seyyid Ali Sultan,” Türk Kültürü ve Hacı Bektaş Veli Araştırma Dergisi 53 (2010), s. 59-87; Rıza Yıldırım, "Muhabbetten Tarikata: Bektaşi Tarikatı'nın Oluşum Sürecinde Kızıldeli'nin Rolü,” Türk Kültürü ve Hacı Bektaş Veli Araştırma Dergisi 53 (2010), s. 153-190. 
sürecinde ise Antalyaddaki Abdal Musa ile tanışıklı̆̆ı olan Kaygusuz Abdal'ın Mısır seyahatinin etkisi olabileceğini fakat bunu ispat edecek yeterli belgenin bulunmadığını belirtir. ${ }^{5}$ Irak’taki Bektaşi tekkeleri konusunda yapılmış değerli bir çalışma ise Osmanlı'nın yeni fethedilen yerlerde zaviye kurmaları için Ahi ve Rum Abdallarına temlik verme siyasetinin 16. yüzyılda devam etmiş olabileceğini öne sürerek Kerbela tekkesini örnek göstermektedir. Yazar, bu tekkenin vakfiyesini inceleyerek, kurucusunun Rum Abdallarından Sadık Dede olduğunu tespit etmiştir. ${ }^{6}$ Bektaşi tekkelerinin coğrafi dağılımı üzerine yapılmış en eski ve günümüzde hala en kapsamlı olma konumunu koruyan çalışma F. W. Hasluck'un eseri olup tüm bu bahsi geçen çalışmaların temelini oluşturmuştur. ${ }^{7}$

İkinci dönem Balım Sultan'la (ö. 922/1516) başlayan esas kuruluş devresidir. $\mathrm{Bu}$ araştırmada bizim daha ayrıntılı olarak inceleyeceğimiz dönem Bektaşiliğin bu ikinci evresidir. Bu devrenin ikinci bir kuruluş kabul edilmesi Bektaşi ananesinde Balım Sultan'ın ikinci pir kabul edilmesiyle onay kazanmış bir olgudur. Balım Sultan 1501'de II. Bayezid tarafından Dimetoka’dan getirtilerek Hacı Bektaş Zaviyesi'nin başına geçirilmiş, dolayısıyla tarikatın şeyhi olmuştur. ${ }^{8}$ Balım Sultan döneminde teşkilat, doktrin, ayin ve erkânın ne derece değişikliğe uğradığı tam bilinmemektedir. Fakat tarikat Kalenderilik, Rum Abdalları ve diğer heteredoks hareketlerle daha iç içe bir görünüm sergilemekteyken bu dönemde ayrı bir örgütlenmeye geçiş yaşamışırı. ${ }^{9}$ Tarikatın ayin ve erkân açısından eski çizgisinden uzaklaşarak günümüze ulaşmış asli çizgisini kazandığı bu dönem sadece manevi alanda değil teşkilat ve işleyiş alanında da büyük değişikliklerin olduğu bir zaman dilimidir. Bu, merkezi örgütlenmenin Bektaşi tarikatına uygulanması sürecidir ki II. Bayezid döneminde ortaya çıkmıştır.

5 Fuad Köprülü, “Mısır'da Bektaşilik,” Türkiyat Mecmuası, c. VI (1939), s. 18-20.

6 Ayfer Karakaya-Stump, "Irak'taki Bektaşi Tekkeleri,” Belleten LXXI, 261 (Ağustos 2007), s. 704.

7 F.W. Hasluck, Christianity and Islam under the Sultans (İstanbul: Isis Press, 2000; ilk baskı 1929). Bu eserde Bektaşi tekkeleri ile ilgili kısım ikinci cildin XLII bölümünde bulunmaktadır. Bu kısım 1928 yılında Ragıp Hulusi tarafından "Bektâşîlik Tedkîkleri" adı altında Osmanlıcaya çevrilmiş Anadolu Dini Tarih ve Entografyasına Dair Tedkikat Merkezi Neşriyatı olarak yayınlanmıştır. Bu eser Yücel Demirel tarafından yeni harflere çevrilerek tekrardan basılmıştır: Frederic William Hasluck, Anadolu ve Balkanlarda Bektaşilik, çev. Yücel Demirel (İstanbul: Ant Yayınları, 1995).

8 John Kingsley Birge, The Bektashi Order of Dervishes (London: Luzac Oriental, 1994), s. 56-57; İ̀ène Mélikoff, Hacı Bektaş Efsaneden Gerçeğe (İstanbul: Cumhuriyet Yayınları, 2010), s. 220-24.

9 Ahmet Yaşar Ocak, "Bektaşilik,” DİA 5 (İstanbul, 1992), s. 373-74. 
Bektaşiliğin II. Bayezid döneminde örgütlü bir hale gelmesi II. Bayezid'in tarikat-devlet ilişkisi çerçevesinde benimsediği yeni yaklaşımın bir yansımasıdır. Fatih Sultan Mehmet döneminde devlet felsefesinin tekkeye değil medreseye dayandırılması, tarikat önde gelenlerine değil ulemaya yakın durulması, II. Bayezid döneminde teşvik edilmemiştir. Tam tersine tarikatların devlet örgütlenmesi altında düzenlenerek toplumun daha etkili bir biçimde denetlenmesi öngörülmüştür. ${ }^{10}$ Bu uygulama sadece Bektaşi tekkelerinin örgütlenmesinde değil diğer tarikatlarda da görülmektedir.

Özellikle, İstanbul'da tarikatların yaygın hale gelmesi II. Bayezid dönemi politikalarının bir sonucu olmuştur. Geçmişte tarihçilerin ortaya atmış olduğu İstanbul'un fethiyle Anadolu'daki birçok tarikatın İstanbul'a geldikleri görüşü bugün kabul edilmemektedir. Değil tarikatların yerleşmesi, sürgünle yerleştirilmiş Müslüman nüfusun dahi şehri sonradan terk ettikleri, nüfus tahrir defterlerinde tespit edilebilmiştir. ${ }^{11}$ Fatih döneminde İstanbul'un tasavvuf hayatı henüz gelişmemiştir. Bunda en önemli sebep imparatorluğa dönüşme iddiasındaki iktidarın

10 Ekrem Işın, “İstanbul'da Tarikat Kültürü ve Gündelik Hayat,” Dergah 6, no. 63 (Mayıs, 1995), s. 13.

11 Halil İnalc1k, The Survey of Istanbul 1455: The Text English Translation Analysis of the Text, Documents (İstanbul: Türkiye İş Bankası Kültür Yayınları, 2012). Yeni fethedilen şehre yerleşmeye dair bir gönülsüzlüğün olduğu bilinmektedir. Bu memnuniyetsizliğin nedenleri çoktur. İstanbul'un bizzat kuşatmasına katılmış geniş bir derviş çevresinin fethin yarattığı olanaklardan çok faydalanamadığ Aşıkpaşazade'nin kendisinin de ev sahibi olduğu İstanbul'da şehrin yeni halkına kira zorunluluğu getirmesini eleştirmesi buna örnek gösterilerek belirtilmiştir. Feridun M. Emecen, Fetih ve Kıyamet 1453 (İstanbul: Timaş Yayınları, 2012), s. 76-77.

Fakat İstanbul'a yeterli nüfusu çekememe ve zorunlu iskan politikalarına gitme ardında ideolojik sebepler de aranabilir. Bu ideoloji ise şehrin hem İslam hem Hıristiyan literatüründe sahip olduğu olumsuz imajdan bağımsız değerlendirilemez. İstanbul'un fethi Osmanlı ilim çevrelerinde daha şehir alınmadan önce dahi kıyametin alameti olarak değerlendirilmiş ve eleştirilmiştir. Bu geniş külliyat içerisinde fetihten yaklaşık yirmi beş yıl sonra yazılmış olan Otman Baba Velayetnamesi ve Sarı Saltuk Menakıbnamesinin de bulunması konumuz açısından oldukça ilginçtir. Otman Baba Velayetnamesinde görüldüğü üzere İstanbul'un Müslüman bir şehir olması için fetih yeterli görülmemektedir. Velayetnamede Sultan Mehmed'in İstanbul'unun zahirde Müslüman olduğu ve ancak Otman Babanın şehre gelmesi ve şehrin onun velayet ve kerametine inanması sonucunda şehrin gerçek Müslümanlığa geçeceği savunulmuştur. Emecen, Fetih ve Klyamet, s. 30-78; Stefanos Yerasimos, Konstantiniyye ve Ayasofya Efsaneleri, çev. Ş. Tekeli (İstanbul: 1993), s. 196-200; Halil İnalcık, "Otman Baba ve Fatih Sultan Mehmed," Doğu 26, (2004), s. 26. 
diğer güç odakları olan eşraf ailelerine ve tarikatlara karşı gücünü arttırmaya çalışmasıdır. ${ }^{12}$

Ancak II. Bayezid dönemine gelindiğinde iktidarın gücünün takviyesi tarikat ve eşrafin desteği ile gerçekleştirilebilmiştir. II. Bayezid henüz Amasya’da şehzade iken Fatih Sultan Mehmet'ten sonra tahta çıacak kişinin Cem Sultan olduğu rivayetleri yaygın bir hale gelmiş idi. ${ }^{13} 1481$ 'de Fatih'in vefatıyla bir saray komplosu düzenlenmiş, bu komplonun ortaya çıkartılması sonucu olayla ilgisi olan şeyhler gizlenmek zorunda kalmışlardı. Bu şeyhlerin II. Bayezid'ı desteklemiş olmaları, yeni sultan tahta çıtıktan sonra ihya edilmeleriyle karşlık görmüştür. Bu şeyhler Halvetiliği İstanbul'da kurumsallaştıran Cemaleddin Halveti ve Bayramiliği etkin hale getiren Muhyiddin İskilibidir. ${ }^{14}$ II. Bayezid dönemi tarikatların İstanbul'da etkin hale gelmeye başladığı dönemdir. Gene bu dönemde Abdullah İlahi aracılığıyla Nakşibendilik de İstanbul'a girmiştir. ${ }^{15}$ II. Bayezid'in tarikatlara vermiş olduğu destek genel itibarıyla Cem Sultana karşı vermiş olduğu mücadele ile ilişkilendirilebilir. Bektaşi tarikatındaki örgütlenmenin diğer bir sebebinin ise Anadolu'daki Türkmen ve Kızılbaş nüfusunu kontrol altında tutmak olduğu düşünülebilir. ${ }^{16} \mathrm{Bu}$ eksende tarikatların devlet erki altında denetimli bir şekilde kurumsallaşmaları ve İstanbul'da da daha yoğun bir görünürlük kazanmaları hedeflenmiştir.

II. Bayezid tarihçiler tarafından genelde sofu bir padişah olarak resmedilmiştir. Desteklemiş olduğu tarikatlar konusunda Sünni yaklaşımın ağırlıklı olduğu da bu düşünceye paralel olarak gelişmiştir. ${ }^{17}$ Fakat II. Bayezid'in Balım Sultan'ı

12 Bu siyaset çerçevesinde hali hazırda vakıf ya da emlak haline dönüşmüş yaklaşık 20.000

(?) kadar çiftlik ve köy, sahipleri olan eski aileler, ulema, şeyh ve dervişlerden müsadere edilmiştir. Halil İnalcık, Osmanlı İmparatorluğu, Klasik Çă̆ (1300-1600) (İstanbul: Yapı Kredi Yayınları, 2013), s. 35; Işın, “İstanbul'da Tarikat Kültürü,” s. 12.

13 II. Bayezid'in tahta çıkması ile Cem Sultan Avrupa ve Memluklular'ın da desteğini alarak II. Bayezid'e karşı ayaklanmıştır. Ayrıntılı bilgi için Nicolas Vatin, l'Ordre de Saint-Jean-de-Jérusalem, l'Empire ottoman et la Méditerranée orientale entre les deux sieges de Rhodes 1480-1522 (Louvain, Paris 1994).

14 II. Bayezid tahta çıktığında İstanbul'da yaşanan olaylar için bkz. Şehabeddin Tekindağ, "Beyazid II.'in Tahta Çıkışı Sırasında İstanbul'da Vukua Gelen Hâdiseler Üzerine Notlar," Tarih Dergisi X/14 (1959), s. 85-96; Işın, "İstanbul'da Tarikat Kültürü,” s. 12-14.

15 Işın, "İstanbul'da Tarikat Kültürü,” s. 13.

$16 \mathrm{Bu}$ isyanların nihayetinde kontrol altına alınamamasını Suraiya Faroqhi I. Selim döneminde Hacı Bektaş Veli Dergahı'nın kapatılmasının nedeni olarak düşünebileceğimizi önermektedir. Suraiya Faroqhi, "The Tekke of Hacı Bektaş: Social Position and Economic Activities," IJMES 7 (1976), s. 185-86.

17 Bkz. Necdet Sakaoğlu, “Bayezid II,” Dünden Bugüne Istanbul Ansiklopedisi 2, s. 84-85. 
bizzat Hacı Bektaş Zaviyesi'nin başına getirmesi Bektaşi vakıflarını zenginleştirmesi ve başta Hacı Bektaş Zaviyesi olmak üzere birçok zaviyenin tamir edilmesi bu dönemde Bektaşiliğin devlet himayesine girdiğini göstermektedir. ${ }^{18}$ II. Bayezid zamanında kaleme alınmış Vilayetnamènin sonunda II. Bayezid'in Hacı Bektaş'a büyük saygı duyduğu ve Hacı Bektaş’ın türbesini ziyaret etmekle kalmayıp türbenin üstünü kurşunla kaplattığı, tekkeye birçok altın verdiği ve vakıf gelirlerini de ziyadesiyle arttırdığı yazmaktadır. ${ }^{19}$

Bu dönemde Bektaşilik diğer tarikatlardan farklı olarak bir taşra teşkilatı kurmuş ve bunları kendine bağlayarak güçlü merkeziyetçi bir sistem oluşturmuştur. Böylelikle bütün tarikat Hacı Bektaş Zaviyesi'ne bağlı hale gelmiştir. Bu tip bir merkezi yapılanma Osmanlı tarikatları içerisinde yalnızca Mevlevilikte ve Bektaşilikte görülmektedir. ${ }^{20}$

Tarikat bünyesindeki vakıfların tarihi oldukça gerilere uzanabilmektedir. Söz gelimi Kızıldeli, Akyazılı ve Abdal Musa zaviyelerinin vakıflarının Selçuklular ve beylikler döneminde kurulmuş olması ve Rum Abdalları arasında sayılan Kalenderi şeyhlerinin zaviyelerinin vakıflara sahip olmaları gibi. Bu vakıfların direkt Hacı Bektaş zaviyesine bağlanması Balım Sultan dönemindeki teşkilatlanma sayesindedir. Arşiv kaynakları göstermektedir ki Osmanlı sınırları içerisindeki tüm Bektaşi tekkelerinin başındaki şeyhlerin atamaları Kırşehir'de varlığını devam ettiren Hacı Bektaş Veli tekkesinin onayı ile yapılmak zorundadır. Bu sistemin tüm 17. ve 18. yüzyıllarda devam ettiği anlaşılıyor. ${ }^{21}$

Balım Sultan döneminde atamalara kadar varan yakın denetim altına alınmış olan Bektaşi tekkeleri ekonomik anlamda da Kırşehir'deki merkezlerine bağlanmışlardır. Bektaşi tekke ve zaviyelerinin vakıflarında her tekkenin mütevellisi arazi ve diğer mallarından elde edilen tüm gelirleri topluyor, mevcut ihtiyaçlar karşılandıktan sonra arta kalanı Hacı Bektaş Zaviyesine gönderiyordu. ${ }^{22}$ Ancak

18 Ocak, "Bektaşilik," s. 378.

19 Hünkar Hacı Bektaş Veli Velayetnamesi, der. Hamiye Duran ve Dursun Gümüşoğlu (Ankara: Gazi Üniversitesi Türk Kültürü ve Hacı Bektaş Veli Araştırma Merkezi, 2010), s. 903-4.

20 Suraiya Faroqhi, "Bektashis: Report on Current Research,” der. Alexandre Popovic ve Gilles Veinstein, Bectachiyya: Etudes sur l'ordre mystique des Bektachis et les groupes relevant de Hadji Bektach (İstanbul: ISIS, 1995), s. 19.

21 BOA, C.EV 137: 6848 (1201/1787); BOA, C.EV 468: 23695 (1156/1743); BOA, C.EV 627: $31650(1222 / 1807)$.

22 Ocak, "Bektaşilik," s. 378. 
bu sistemin nasıl çalıştı̆̆ını ayrıntılı olarak gösterebilecek belgelere arşivlerde rastlanamamıştır.

Bu merkezi ekonomik yapılanma 15. ve 16. yüzyıllardan itibaren Bektaşi tarikatını bir ekonomik güç haline getirir. Suraiya Faroqhi, Kırşehir'deki Hacı Bektaş Veli tekkesinin vakıf gelirlerine dair yaptığ 1 araştırmada tekkenin gelirlerinin 99.000 akçeye kadar ulaştı̆̆ını göstermektedir. ${ }^{23}$ Yazarın da belirttiği gibi dikkatle yaklaşılması gereken yaklaşık bir değer olmasını göz önüne almak kaydıyla tekkenin Orta Anadolu'nun en güçlü ekonomik kurumlarından biri olarak ortaya çıktığını göstermektedir. Aynı dönemde Kırşehir'deki diğer vakıflara bakıldığında geliri 10.000 akçenin üstüne çıkanların çok az sayıda olduğu ve bunların dahi Hacı Bektaş Veli tekkesinin gelirlerine yaklaşamadığı görülür. Örneğin Caca Bey medresesinin geliri 23.673 akçe, Ahi Evran zaviyesininki 32.790 akçe ve Aşık Paşa zaviyesinin 31.038 akçedir. Meseleye tarikatlar arasında bir sıralama ekseninde bakılacak olursa Bektaşi vakıflarının zenginlik açısından Mevlevi vakıflarından hemen sonra geldiği söylenebilir. ${ }^{24}$

II. Bayezid döneminde temeli oluşturulmuş bu teşkilat yapısı Yeniçeri Ocağı' nın kapatılışına kadar devam etmiştir. 1826'da Yeniçeri Ocağı' nın kapatılması ise Bektaşiliğe büyük bir darbe vurmuştur. Bektaşilikle ilgili literatürü incelediğimizde çoğunlukla çalışmaların bu döneme konsantre olduğunu görüyoruz. ${ }^{25}$ Bunun nedeni hem daha önceki döneme ait belgelerin bulunmayışı hem de 1826'nın Bektaşiliğin tarihinde önemli bir kırılma ve değişim yaratmış olmasındandır. 1826'da birçok Bektaşi tekkesi yıkılmış, kapatılmış ve vakıf mallarına el konulmuştur. Devam etmesine izin verilenler ise en azından görünürde çoğu Nakşibendi veya bazen Kadiri tarikatını takip eder hale gelmiştir. Fakat Bektaşi dervişleri bu tekkelerde gizli de olsa faaliyetlerine devam etmiş ve hatta I. Abdülmecid döneminde eski durumu tekrardan canlandırmaya çalışmışlardır. Bu süreç 1925 'te tüm tekke ve zaviyelerin kapatılmasına kadar devam etmiştir.

23 Faroqhi, "The Tekke of Hacı Bektaş," s. 193.

24 Faroqhi, "The Tekke of Hacı Bektaş," s. 194.

25 Mesut Ayar, Bektaşilikte Son Nefes: Yeniçeriliğin Kaldırılmasından Sonra Bektaşilik (İstanbul: Giza, 2009); Aydın Soyer, 19. Yüzyılda Bektaşilik (İzmir: Akademi Kitabevi, 2005); Muharrem Varol, Islahat, Siyaset, Tarikat: Bektaşiliğin İlgası Sonrasında Osmanlı Devletinin Tarikat Politikaları (1826-1866) (İstanbul: Dergah Yayınları, 2013). 


\section{Bayezid Dönemi ve İstanbul'daki Bektaşi Tekkeleri}

II. Bayezid zamanında İstanbul'da örgütlenen tarikatları canlandıranlar arasında ilk olarak sayılması gerekenler Halvetiliği yaygınlaştıran Cemaleddin Halveti $^{26}$ ile Bayramiliği yaygınlaştıran Muhyiddin İskilibi ve Nakşibendiliği yaygınlaştıran Abdullah İlahi'dir. ${ }^{27}$ Bunlara Mevleviler ve Balım Sultan altında teşkilat yapısını tamamlamış Bektaşiler de dahil olmuştur. II. Bayezid'le başlayan bu süreç 17. yüzyıl başlarına kadar devam etmiştir. Bu dönemde İstanbul'a gelen tarikatlar genellikle Horasan kökenli kalmıştır. 17. yüzyıldan sonra ise Arap kökenli Kadirilik, Rıfailik, Şazelilik ve Sa'dilik İstanbul'da örgütlenmeye başlamıştır. ${ }^{28}$

II. Bayezid döneminde tüm Osmanlı topraklarında Hacı Bektaş Zaviyesi’nde Balım Sultan'ın şekillendirdiği adap ve erkân doğrultusunda örgütlenen Bektaşilik, İstanbul'da nasıl bir yapılanma sürecinden geçmiştir? İstanbul'daki Bektaşi tekkelerinin ne zaman vakıf haline geldiğine dair net veriler çoğu zaman yoktur. Fakat kuruluş anekdotu olarak İstanbul'un fethinde bulunmak için gelen Horasan erenlerinin İstanbul'da mevcut zaviyeleri kurduğuna dair vurgu, ilerde örneklerini göreceğimiz üzere, birçok tekkede gözlemlenmektedir. Bu tekkelerin vakıflaşmasının İstanbul fethinden hemen sonra değil de, II. Bayezid dönemi içerisinde gerçekleştiğini düşünmek pek de yanlış olmayacaktır.

Nitekim 19. yüzyılda hakkında kapatılma kararı verilmiş tekkeler arasında vakıf olanların Sultan II. Bayezid vakfına bağlanmasının tesadüfi olmadığı kanaatindeyiz. Belgelerden anlaşıldığı üzere Yeniçeri Ocağı’nın kaldırılmasıyla birlikte İstanbul'da kapatılan veya Nakşibendi tekkesi olarak devamına karar verilen Bektaşi tekkelerinin arsa, mülk ve zaviyedarlıkları ile türbelerinin yıkılıp yıkılmayacağı belirli esaslara göre karara bağlanmıştır. Arsa ve mülklere dair kullanılan kriter vakıf olanların Sultan II. Bayezid vakfı tarafından, mülk olanların ise mîrî

26 II. Bayezid tahta geçtikten sonra Hosios Andreas Kilise ve manastırını dönemin kapıcıbaşısı, ve daha sonra sadrazamı olacak, Koca Mustafa Paşa’ya vermiş burası cami ve tekke kompleksine çevrilmiştir. Amasya'dan davet edilen Çelebi Muhammed Cemaleddin Halife Halvetiliği İstanbul'da örgütlemek için meşihatine bu tekkede devam etmiştir (1486-91). Gene aynı dönemde (1490-98) Yedikule'deki Saint Jean de Stoudios Kilisesi II. Bayezid'in Lalası olan İmrahor İlyas Bey tarafından cami ve tekkeye çevrilmiş, burada Çelebi Halife'nin halifelerinden olan İbrahim Menteşevi'nin meşihati devam ettirilmiştir. Natalie Clayer ve Nicolas Vatin, "Un Établissement de Derviches Stambouliote: Le tekke d'İmrahor," Anatolia Moderna-Yeni Anadolu VI (1996), s. 31-81.

27 K. Kufralı, "Molla İlahi ve Kendisinden Sonraki Nakşbendiyye Muhiti," Türk Dili ve Edebiyatı Dergisi III/1-2 (1949), s. 129-151.

28 Işın, “İstanbul'da Tarikat Kültürü,” s. 13. 
tarafından zapt edilmesi ve Bektaşi babalarından evladı olanlara terk edilmesidir. Türbelerin yıkılıp yıkılmayacağı da verilen şeyhülislâm fetvasına göre gerçekleşmiştir. ${ }^{29}$ Yapılan işlemlerle ilgili tutanaklara baktığımızda ise gerçekten bazı tekkelerin II. Bayezid vakfına ait olarak işleme tabi tutulduğunu görüyoruz.

İleride göreceğimiz üzere, geç dönemde vakıf olmuş tekkelere değil, II. Bayezid döneminde kurulmuş olma olasılığı yüksek olan tekkelere böyle bir muamele yapılmıştır. Dolayısıyla, her ne kadar bahsi geçen Bektaşi tekke ve zaviyelerinden II. Bayezid'in vakfiyesinde bahsedilmiyor olsa da bu dönemde vakıf oldukları ve kapatılma esnasında da bu sebepten ötürü II. Bayezid vakfı tarafından zapt edildiğini düşünmek doğru olacaktır.

İstanbul'daki Bektaşi tekkelerinin teşkilatlanmasını Yeniçeri Ocağı'ndan bağımsız düşünmek mümkün değildir. Bu devrede her şeyden önce Balım Sultan’ın getirmiş olduğu mücerretlik (bekarlık) erkânı Bektaşilik ve Yeniçeri Ocağı arasında uyumun arttırıldığı bir süreci başlatmıştır. ${ }^{30}$ Kaldı ki Yeniçeri Ocağı'nın bizzat Hacı Bektaş Veli'den dua almış olduğu bazı araştırmacılar tarafından ortaya atılmış bir iddiadır. Fakat İsmail Hakkı Uzunçarşılı, Hacı Bektaş่ın 13. yüzyılın son yarısında vefat ettiğini ve Osmanlı hanedanıyla herhangi bir iletişime girmiş olmasının mümkün olmadığını ifade eder; bu sebeple de Ocağın Bektaşilikle ilişkisinin 14. yüzyıl sonuyla 15. yüzyıl başı arasındaki bir zaman diliminde gerçekleşmiş olabileceğini iddia eder. ${ }^{31}$ Ocakla tekke arasındaki ilişki elbette bununla da sınırlı değildir. Aşıkpaşazade tarihi, Abdal Musa’nın Orhan Gazi zamanındaki gazalara katıldığını ve gazada yeniçerinin birinden bir üsküf alarak giydiğini Bektaşilerin elifli tacı'nın esasının bu üsküf olduğunu belirtir. ${ }^{32}$

Yeniçeri Ocağı'na aynı zamanda Ocak-1 Bektaşiyan; yeniçerilere taife-i bektaşiye veya zümre-i bektaşiyan; ocaktaki terfi silsilesine de silsile-i tarik-i bektaşiyan denilmektedir. Ocağın işleyişinde Bektaşiliğin önemini vurgulayan çalışmalara baktığımızda bu isimlendirmelerin pek de yersiz olmadığını görmekteyiz. Yeniçeriler Bektaşi yolunu izler, onun adap ve erkânını takip ederler. ${ }^{33}$ Dahası Ye-

29 BOA, HAT 293, no. 17453 (1241/1826).

30 Erdal Küçükyalçın, Turna’nın Kalbi: Yeniçeri Yoldaşlığı ve Bektaşilik (İstanbul: Boğaziçi Üniversitesi Yayınları, 2010), s. 136-38.

31 İsmail Hakkı Uzunçarşılı, Osmanlı Devleti Teşkilatı'nda Kapıkulu Ocakları, I, Acemi Ocă̆ı ve Yeniçeri Ocăğ (Ankara: Türk Tarih Kurumu Basımevi, 1943), s. 150.

32 Birge, The Bektashi Order of Dervishes, s. 46; Köprülü, "Mısır'da Bektaşilik," s. 16.

33 Ocak içindeki Bektaşi gelenekleri bu makalenin konusu dişında olmakla beraber bu konuda yapılmış değerli çalışmaları belirtmek gerektiğini düşünmekteyiz. Bu konudaki 
niçeri Ocă̆g'nın 94. Cemaat ortasında bir Bektaşi babası bulunduğunu ve bu babanın Yeniçeri ağalığı atamalarında dahi fikir beyan edebilecek güçte olduğunu Uzunçarşılı'nın eserinde görmekteyiz. ${ }^{34}$ Yakın dönemde yazılmış son derece değerli bir çalışmaya göre, Bektaşi tarikatının Yeniçeri Ocağı'ndaki etkisinin kanun ve ananelere kadar nüfuz etmesinin ötesinde Ocağın Bektaşi tekkesinin aynı zamanda bir askeri akademi gibi de işlediği öne sürülmüştür. ${ }^{35}$

Görüldügü üzere, bugüne kadar yapılmış birçok çalışma yeniçerilerin almış olduğu tekke eğitimine vurgu yapmış, Yeniçerilerin Bektaşiliği üzerinde durmuştur. Bu değerli çalışma ve yaklaşımlara bir katkı olarak makalemiz bu ilişkiyi tersinden değerlendirmekte ve Yeniçerilerin Bektaşi tekkelerine bir etkide bulunup bulunmadığını sorgulamaktadır. Yeniçeri Ocağı ve Bektaşi tekkeleri arasındaki ilişkinin ocak ve Bektaşi tekkeleri arasında nasıl bir formel yapı ekseninde oluşturulduğuna dair bu güne kadar somut bir veri tespit edilememiştir. Meseleye bu cepheden de bakmak yerinde olacaktır.

Yaptığımız araştırma Yeniçeri-Bektaşi ilişkisinin sadece adap ve erkân düzeyinde kalmadığını, iki teşkilat arasında idari bir takım bağlar da kurulduğunu göstermiştir. Bu iddiayı destekleyen önemli veriler vardır. Biri İstanbul'da II. Bayezid döneminde kurulmuş Bektaşi tekkeleri arasında olan Karaağaç Tekkesi'nin bu ilişki bağlamındaki özel konumudur. Tarikat geleneğine göre, yeniçeri kışlasındaki 94. Cemaat ortasında tarikatı temsil eden Bektaşi babasının Karaağaç Tekkesi postnişinliğinden geçtiği geçmişte kanıtlanmıştır. ${ }^{36}$ Kasımpaşa bölgesinde

başlıca eser İsmail Hakkı Uzunçarşılı’nın Kapıkulu Ocakları üzerine hazırlamış olduğu 2 ciltlik eseridir. Bektaşilik üzerine yazılmış en önemli monografilerden biri olan John Kingsley Birge'nin eseri de Ocak'taki Bektaşi yolunun ocağ değer olduğundan bahseder. Son dönemde Erdal Küçükyalçın'ın yayınlamış olduğu çalışma ise bu konuya yoğunlaşmış değerli bir katkıdır. İsmail Hakkı Uzunçarşılı, Osmanlı Devleti Teşkilatında Kapıkulu Ocakları, 2 c. (Ankara: Türk Tarih Kurumu Basımevi, 1943); John Kingsley Birge, The Bektashi Order of Dervishes (London: Luzac Oriental, 1994); Reha Çamuroğlu, Yeniçerilerin Bektaşiliği ve Vaka-i Şeriyyesi, (İstanbul: Ant Yayınları, 1991); Erdal Küçükyalçın, Turna’nın Kalbi: Yeniçeri Yoldaşlığı ve Bektaşilik (İstanbul: Boğaziçi Üniversitesi Yayınları, 2010).

34 Uzunçarşılı, Osmanl Devleti Teşkilatı'nda Kapıkulu Ocakları, c. 1, s. 159, 178, 253. Uzunçarşılı Yeniçeri Ocağı'nın Bektaşi babasının 99. Cemaatin ortasında olduğuna dair ikinci görüşün olduğunu da belirtmiş̧ir. D’Ohsson'a göre Yeniçerilerin Bektaşi babası 99. cemaatin ortasındadır. Fakat, Başbakanlık Osmanlı Arşivindeki mevacib defter kayıtlarında 94. Ortanın 'ocak-1 imam' olarak kaydedilmesi Uzunçarşılı'nın görüşünü teyid eder. Örneğin, BOA, KK 6599, no. 236, 468 (1074-75/1663-64).

35 Küçükyalçın, Turna’nın Kalbi, s. 180-85.

36 Ekrem Işın, "Bektaşilik," Dünden Bugüne İstanbul Ansiklopedisi 2 (1994), s. 134. 
Südlüce'nin Karaağaç mahallinde kurulmuş olan bu tekke, belgelere yansıdığına göre, II. Bayezid vakfından kabul edilerek kapatılma işlemi yapılmıştır. ${ }^{37}$ Yani bizzat II. Bayezid'in fonlarıyla kurulmuş veya daha önce bahsi geçmiş büyük Bektaşi zaviyeleri gibi varlığı devlet tarafından bu sırada tescillenip II. Bayezid vakfına bağlanmıştır. Bir diğer olasılık ise bu dönemde belki devlet ricalinden kişilerin de desteğini alarak tekkeye ait bir vakıf kurulmuş olduğudur. Vakfiyesi elimize ulaşmadığından, bu argümanı kesin sonuçlandırmak mümkün değilse de II. Bayezid dönemine vurgu yapmak yerinde olacaktır. Kurumsallaşmanın yaşandığını bildiğimiz II. Bayezid döneminin Bektaşi tekkelerinin kapatılması esnasında tekrardan referans olarak kullanılması ve Karaağaç tekkesinin II. Bayezid vakıfları tarafından zapt edilmesi tesadüfi değildir. Devlet himayesi ile Bektaşi tarikatının yeniden örgütlendiği II. Bayezid döneminde İstanbul tekkeleri ile Yeniçeri Ocağı arasındaki ilişkinin de yeniden düzenlendiğini gösterir. II. Bayezid devrinde kurumsal bir yapı kazanmış Karaağaç tekkesi aynı zamanda Yeniçeri Ocağı'nın Bektaşi babası olma yolunda elzem bir durak haline getirilmiştir.

Literatürde sürekli karşılaştığımız Yeniçerilik ve Bektaşiliğin iç içe geçmişliği hususunda arşiv kaynakları böyle bir ilişkinin gerçekten olup olmadığını sorgulatacak kadar sessiz kalabilmektedir. Bu araştırma kapsamında tespit edebildiğimiz en önemli belgelerden biri ise bu ilişkinin resmi bir bağlama oturtulduğunu kanıtlar niteliktedir. Belge, bizzat Hacı Bektaş Veli tekkesi şeyhlerinin atamalarının Yeniçeri Ağası'nın arzı ile gerçekleştirildiğini gösterir. ${ }^{38}$ Bugüne kadar yapılmış çalışmalarda arşivlerde de sıkça rastladığımız belgeler doğrultusunda taşra şeyhlerinin Kırşehir'deki Hacı Bektaş Veli tekkesi şeyhi arzıyla atandıkları tespit edilmiştir. ${ }^{39}$ Bu belgede ise Kırşehir'de bulunan Hacı Bektaş-1 Veli evkafı tevliyet ve meşihatinin bir Ali'den diğer Ali’ye tevcihi Yeniçeri Ağası Hacı Mehmed Paşa’nın arzı üzerine yapılmıştır. Bu demektir ki Kırşehir'deki şeyhin tayini Yeniçeri Ocağı'nın onayı, rızası, arzı olmadan yapılamaz. Devletin yeni şeyhi tanıması için yeniçerilerin tasdikinden geçmesi gerekmektedir. Bu resmi statü yeni Bektaşi babasının atanması ile ilgili teşrifatta da kendini gösterir. Yeni atanan Hacı Bektaş Veli tekkesindeki baba, görevine başlamadan önce yapılan teşrifatta İstanbul'a gelir yeniçerilerin oluşturduğu alay onu Ağa kapısına getirir. Burada Yeniçeri Ağası

37 BOA, MAD $9731(1242 / 1826)$.

38 BOA, İE.EV 5707 (1114/1702).

39 Suraiya Faroqhi, "Einflusskämpfe, Strukturfragen und die stets problematische Rolle der Janitscharen: ein Beitrag zur Geschichte der Bektaschis vor 1826," Journal of Turkish Studies 26, no. 1 (2002), s. 215-227. 
tacını giydirdikten sonra alay onu Bab-1 Aliye götürür ve sadrazam tarafından kendisine ferace giydirilirdi. ${ }^{40}$

Yeniçeri Ağası'nın Hacı Bektaş Veli tekkesi şeyhi tayinindeki bu arz etme yetkisinin II. Bayezid döneminde ortaya çıkmış olduğuna dair elimizde bir veri yoktur. Ancak Yeniçeri Ağası'nın Bektaşi şeyhleri üzerindeki bu yetkisinin bu dönemde veyahut II. Bayezid dönemini takip eden süreç içerisinde uygulamaya konmuş olması kuvvetle muhtemeldir. Nasıl ki bu dönemde Osmanlı sınırları içerisindeki tüm Bektaşi tekkelerinin şeyh atamaları Hacı Bektaş-1 Veli tekkesine bağlanarak bir merkezileşmeye gidildiyse, aynı şekilde bu merkez tekkenin atamalarının Yeniçeri Ağalığı’na bağlanması da bu teşkilatlanmayı tamamlamış önemli bir aşama olabilir. Meşihat ve tevliyet atamalarının ancak Yeniçeri Ağası arzı ile yapılabiliyor olması Bektaşi tarikatının kurumsal organizasyonu üzerinde Yeniçeri Ocağı'nın yetkili bir üst merci olarak bulunduğunun ve iki kurum arasında organik bir bağ olduğunun en açlk göstergesidir.

Bu organik bağın nereye kadar gittiğini henüz arşiv bize ifşa etmemiştir. Fakat bunun atama yetkisinden daha geniş bir yetki olduğunu düşünmek mümkündür. Yeniçeri Ocağı belki bir denetleyen, finanse eden, destekleyen, ve hatta koruyan bir kurum olarak zaman zaman Bektaşi tekkeleri üzerinde işlev görmüş olabilir mi? Tarih sayfalarında dağınık olarak bulduğumuz bilgiler bunun olası olduğunu düşündürmektedir. Tıpkı Seyyid Gazi türbesinde her yıl yapılan büyük kutlamalara çok sayıda yeniçerinin ve acemi oğlanının katılması ve koruyuculuk yapması gibi. ${ }^{41}$

Tarikat içerisinde yapılan düzenlemenin idari merkezileşme olduğu kadar Kırşehir'de bir üst ekonomik birimi de şekillendirmiş olması -tekkelerin her sene oraya belirli bir miktar gelir aktarması - Yeniçeri Ocağı ile Bektaşi tekkeleri arasında da bir ekonomik ilişki kurulup kurulmadığını sormamızı gerektiriyor. Yeniçeri Ocağ1 Bektaşi tekkelerini finanse eden bir kurum olarak düşünülebilir mi? Veya Hacı Bektaş Veli zaviyesinin yıllık bütçeleri Yeniçeri Ağası tarafından denetleniyor olabilir mi? Bektaşi tekkelerinin Ocakla ekonomik ilişkileri bir yana kendi ekonomik faaliyetleri hakkındaki veriler bile son derece kısıtlıdır. Fakat bazı örnekler kısmen de olsa bir ekonomik ilişkinin de olası olduğuna işaret etmektedir. Örneğin,

40 Ayrıca Kırşehir'deki Hacı Bektaş şeyhi tarafından Ocağa verilen beyaz bayrak da alaylarda Yeniçeri Ağası önünden giderdi. Uzunçarşılı, Kapıkulu Ocakları, s. 150, 290; Birge, The Bektashi Order of Dervishes, s. 74.

41 Suraiya Faroqhi, "Seyyid Gazi Revisited: The Foundation as Seen Through Sixteen and Seventeenth-Century Documents," Turcica 12 (1981), s. 96. 
1028/1618-19'da Hacı Bektaş Veli türbesinin çatısında yapılan tamirin masraflarını Yeniçeri Kethüdası karşılamıştır. ${ }^{42}$ Bir diğer örnek ise bizim tespit ettiğimiz bir belgedir. Belgeye göre Ocak kapatıldığında Yarımca Baba tekkesi vakfına, ocak vakfina ait bir araziden ferağen 24 kuruş devredilmiştir. ${ }^{43}$

Bu iki örgütlenme evresi de -Yeniçeri Ocağı'nın Bektaşi babasının İstanbul'daki Karaağaç tekkesinden geçtiği ve merkez olan Hacı Bektaş Veli zaviyesinin şeyhliğinin de Yeniçeri Ağası tarafından arz edilmesi- bize tarikatın kurumsal bir yapıya kavuşmasının bu iki teşkilatı koparılamaz bir bağ ile birbirine bağladığını gösterir. Bektaşi tarikatının yeniden yapılandırma sürecinde İstanbul'da Bektaşilik adeta askeri zümrenin sınırları içerisine alınmıştır. Bir diğer çarpıcı uygulama ise emekli yeniçerilerin bazı tekkelerin başına atanmasıdır. 1730 'da emekli bir yeniçeri Ramazan Baba tekkesine zaviyedar olarak atanmıştır. Gene Demir Baba Velayetnamesinde Seyit Ali Sultan Aşağı Tekkeye yeniçerilerin şeyh olarak atandığını bildirmektedir. $^{44}$

II. Bayezid dönemi teşkilat yapılanmasının sonucunda kurulmuş ve İstanbul'daki Bektaşi tekkelerinin en önemlilerini oluşturmuş bu tekkeler, coğrafi konumları itibarıyla oldukça stratejik noktalardadır. Yarımca Baba tekkesi Boğazı kontrol eden bir konuma sahiptir. Yedikule'deki Mehmed Efendi Tekkesi Yeniçerilerin aktif görevde bulundukları Yedikule hisarının yakınındadır, Karaağaç Tekkesi birçok Sultanın göç ettiği Karaağaç bahçesinin yakınındadır ve Rumelihisarı’ndaki Şehidlik Tekkesi de Boğaz kontrolü açısından önemli bir noktadadır. Söz konusu tekkelerin yeniçerilerin yoğun olarak konuşlandırıldığı bölgelerde bulunmaları Ocak ile İstanbul Bektaşi tekkeleri arasındaki ilişkinin bir başka göstergesi olarak yorumlanabilir.

İstanbul'daki diğer Bektaşi tekkelerini incelediğimizde ortaya çıkan odur ki kadim kabul edilen tekkelerin çoğu II. Bayezid zamanına kadar uzanmaktadır. Haklarında arşiv kaynaklarının son derece sınırlı olmasına rağmen, tespit edebildiğimiz belgeler bu tekkelerin çoğunun kuruluş zamanları ile ilgili bir fikir oluşturmamızı sağlar. Karaağaç tekkesi gibi Yedikule'deki Mehmed Efendi Tekkesi ve Rumelihisarı'ndaki Şehidlik tekkesi de II. Bayezid vakfı üzerinden işlem görmüş kadim tekkelerdir. Bunun yanı sıra, Merdivenköy'deki Şahkulu Sultan, Üsküdar'da Karaca Ahmed Sultan, Paşalimanı'nda Yarımca Baba ve Rumelihisarında Durmuş

42 Birge, The Bektashi Order of Dervishes, s. 74-76.

43 BOA, EV.MH 2409 no. 89 (1290/1873).

44 Faroqhi, Anadolu'da Bektaşilik, s. 139, 142. 
Dede tekkeleri de II. Bayezid dönemi veya sonrasında 17. yüzyılın başlarına kadar devam etmiş olan örgütlenme dönemi içerisinde kurulmuştur.

Kuruluş zamanları hem Bektaşi tarikatının İstanbul içindeki örgütlenmesinin gerçekleştiği II. Bayezid ve sonrası dönemini, hem de 19. yüzyıldaki ikinci yapılanma dönemini göstermesi açısından oldukça büyük bir önem arz etmektedir. 18. yüzyıl sonu ve 19. yüzyıl başlarında karşımıza İstanbul'da kurulmuş üç büyük tekke çıkmaktadır: Karyağdı Baba Tekkesi, Nur Baba Tekkesi ve Tahir Baba Tekkesi. Bektaşi tekkelerinin kapatılmasına kısa bir zaman kala bu büyük tekkelerin kurulması değerlendirilmesi gereken bir konudur.

\section{Karaağaç Tekkesi}

Karaağaç Tekkesi İstanbul'da faaliyet gösteren Bektaşi tekkeleri içerisinde en eski ve tarikat organizasyonu açısından en kıdemli olanıdır. ${ }^{45} \mathrm{Ne}$ zaman kurulduğu ve postnişinlerinin kimler olduğu hakkında net bir bilgi yoktur. Fakat bahsedildiği üzere, tekke II. Bayezid döneminde yeniden örgütlenen tarikat yapısı içerisinde kurulmuş veya evkafı tescillenmiştir. Hacı Bektaş Pir Evi'nin vekili bu tekkede bulunduğu gibi Yeniçeri Ocağı'nın Bektaşi babaları da bu tekkeden gelmiştir. Dolayısıyla, kuruluşu 16. yüzyıl başlarına kadar çekilebilir. Atilla Çetin'in transkripsiyonunu yaptığı 1199/1784 tarihli müfredat defterinden öğrendiğimize göre bu tekke Bektaşi Ali Baba Zaviyesi olarak da bilinmektedir. ${ }^{46}$

Postnişinleri bilinmemekle beraber 1195/1781'de şeyhliği Sarı Sofu Hüseyin Baba’ya tevcih edilmiştir. ${ }^{47}$ Kısa bir süre sonra zaviyedarlığa Salih Baba getirilmesi gerekirken başka bir zat atanmış, daha sonra nizama uyulmadığı gerekçesi ile dava açlıp meşihat Salih Baba'ya verilmiştir. ${ }^{48}$ Bu dönem arşiv belgelerinde tekkenin adı daha çok Sarı baba tekkesi, Sarı Sofu Hüseyin Baba veya Hüseyin Baba tekkesi olarak geçmektedir.

Tekke, sur dışında olması itibariyle gözden ırak izlenimi verse de Karaağaç bölgesi aslında sultan ve maiyetinin yoğun olarak kullandığı bir bölge olmuştur.

45 Işın, "Bektaşilik," s. 134.

46 Atilla Çetin, “İstanbul'daki Tekke, Zaviye ve Hankahlar Hakkında 1199/1784 Tarihli Önemli Bir Vesika," Vakıflar Dergisi XIII (1981), s. 589.

47 BOA, C.EV 493, gömlek 24903, (1195/1781)

48 BOA, C.EV 509, gömlek 25727 (1199/1784); BOA, C.EV 473, gömlek 23903 (1214/1800). 
Karaağaç bölgesindeki hassa bahçelerinden olan Karaağaç bahçesine her yıl haremden göç olmakta Sultan da bu göçe iştirak etmektedir.

Bu tekke 1826'da Yeniçeri Ocağı'nın kapatılması ile birlikte yıkılmış, şeyhi Vekil İbrahim Baba ve tekkeye bağlı diğer altı Bektaşi dervişi Birgi'ye sürülmüştür. ${ }^{49}$ Gene tekkeye bağlı Derviş Yusuf, Derviş Talib ve Derviş Ali, tekkede misafir olarak bulunan derviş Hacı Hasan, Hacı Süleyman, Derviş Mehdi ve Derviş Mehmed ile birlikte Amasya’ya sürülmüştür. ${ }^{50}$ Bir diğer misafir Antepli Derviş Mustafa da Güzelhisar'a gönderilmiştir. ${ }^{51}$ Bundan sonra tekke Hasib Baba Dergâhı olarak devam etmiştir. ${ }^{52}$

Karaağaç tekkesinin kapatılışında el konulan araziler diğer tekkelerle karşılaştırıldığında burasının oldukça büyük bir tekke olduğu izlenimini vermektedir. 1826 'da tekkenin el konan arazisi 16.000 zirâ olarak kayda geçmiştir. Bunun 6.000 zirâ arsası II. Bayezid vakfından olup şeyh tarafından zapt olunmuştur. ${ }^{53}$ Kubbeli ve demir pencereli olarak tasvir edilen dergâh tamamen yıkılmış, fakat pencereler yıkımdan önce sökülmüştür. ${ }^{54}$

Gene 1854 yılına ait bir belge bu Bektaşi tekkesinin de içinde bulunduğu II. Bayezid'e ait vakıf arazilerinin kimlere satıldığının bir tarihçesini bize sunmaktadır. ${ }^{55}$ Buna göre Karaağaç tekkesinin de bulunduğu 10 dönümlük ve 1200 akçe mukataası olan arazi 1826 senesinde Halife el-Hac Ali Ağaya satılmıştır. Bedeli 150 kuruş tapu değeridir. Bu satış esnasında tekkenin Bayezid Baba’nın kontrolünde olduğu ve eşcarının 500 kuruşluk muaccele bedeli ile miriden satıldığı ve bedelin Darphane-i amireye teslim edildiği belirtilmiştir.

Bu bölgede bulunan ve gene II. Bayezid vakfına ait olan ve sınırları Yağhane deresi, Yahudi mezarlığı ve diğer taraflardan da Karaağac'a giden yol ve bir ana

49 BOA, C.ZB. 46, no. 2282 (1241/1826).

50 BOA, C.ZB. 34, no.1680 (1255/1840).

51 BOA, C.ZB. 2282 (1241/1826).

52 İrène Mélikoff, "L’ordre des Bektaşi aprés 1826," Turcica XV (1993), s. 162-164, 171.

5316.000 zirâlık arazi toplam yaklaşık 10 dönüm (9,777 dönüm) kadar arsadır. Tabii ki Anadolu'daki bazı tekkelerin büyük araziler üzerinde tarım yapıp bir çiftlik ekonomisi oluşturduğunu, mesela Antalya’daki Abdal Musa Tekkesinin 9500 dönümlük bir arazide buğday ve arpa ürettiğini düşünecek olursak bu arsa oldukça küçük kabul edilebilir. Ancak İstanbul içinde bu oldukça geniş bir alandır. Abdal Musa Tekkesinin ekonomik fonksiyonları için bkz. Suraiya Faroqhi, Anadoluda Bektaşilik, s. 95-97.

54 BOA, MAD 9371, no. 406 (1242/1826).

55 VGM, EV.MH 748, no. 177 (1271/1854); BOA, EV.MH 748, no. 178 (1276/1859). 
yol ile sınırı çizilen 500 kuruş değerindeki araziyi de tekrardan Halife el-Hac Ali Ağa almış fakat bir sene sonra Ayşe Hatun binti Osman adlı şahsa satmıştır. Daha sonra bu arazi tekrardan el değiştirmiş ve bunun üzerine atanan görevli ve mühendisler tarafından arazinin incelenmesine mahkeme ihtiyaç duymuştur. Oldukça kıymetli olduğu anlaşılan bu arazi daha sonra da birçok kez el değiştirmiş ve bu mülke sahip olmuş kişiler arasında Humbaracı emeklilerinden olan es-Seyyid Ahmed Ağa, Mehmet Azat Ağa b. İbrahim Ağa ve es-Seyyid Derviş Hasan Basri zikredilmiştir.

\section{Erikli Baba, Mehmed Efendi ve Perişan Baba Tekkesi}

Perişan Baba tekkesi Yedikule kapısı dışında Kazlıçeşme bölgesinde, bugünkü Zeytinburnu'nda Zakirbaşı Sokağında mahalleye de adını veren çeşmenin yakınında bulunmaktadır. ${ }^{56}$ Arşiv belgelerinde üç zatın ismi birden anılarak bu tekke zikredilir: Mehmet Baba, Perişan Baba ve Eryek veya Erikli Baba. Tekkede yapılmış sözlü tarih çalışmasında, orada kabri bulunan Eryek Baba'nın İstanbul'un fethine katılmış olan Ahi, Kalenderi veya Abdalan zümrelerinden olduğunun kabul edildiği ve kış günü erik bulmasıyla anıldığı tespit edilmiştir. ${ }^{57}$ Eryek Baba’nın mezarında iki devşirme sütunu bulunmaktadır. Tekkenin kurucusu olmasından ziyade daha sonradan Bektaşi tekkesinin hatırasına sahip çıktığını düşünmek daha yerinde olacaktır. Bahsi geçen Mehmet Baba ise tekkede kabri bulunan Seyyid Mehmed Baba’dır (ö. 1214/1799-1800), ondan önce meşihat görevinin Ahmed Baba’da (ö. 1787) olduğu anlaşılmaktadır.

Her sene tekke yönetimini temsilen bir dervişin Kırşehir'deki Hacı Bektaş Tekkesi'ne gönderildiği bilinmektedir, fakat bu uygulamanın ne zaman başladığına dair bir bilgi yoktur. ${ }^{58}$ Fakat bulunduğu yer olan Yedikule Hisarı'nın yeniçerilerin başlıca görev mevkilerinden biri olması itibarıyla ocakla ilişki sonucu burada kurulmuş olduğu düşünülebilir. ${ }^{59}$

56 Baha Tanman, "Perişan Baba Tekkesi," Dünden Bugüne İstanbul Ansiklopedisi 6 (İstanbul: Tarih Vakfi Yayınları, 1994), s. 242.

57 Nicolas Vatin ve Thierry Zarcone, "Le tekke bektachi de Kazlıçeşme: I. Étude historique et épigrahique," Anatolia Moderna-Yeni Anadolu VII (1997), s. 79-109, 80.

58 Thierry Zarcone, "Les couvents Bektachis d'Istanbul," der. Alexandre Popovic ve Gilles Veinstein, Bectachiyya: Études sur l'ordre myst'que des Bektach's et les groupes relevant de Hadj' Bektach içinde (İstanbul: İsis, 1995), s. 205.

59 Baha Tanman, "Perişan Baba Tekkesi," s. 242. 
Yeniçeri Ocağı'nın kapatılmasıyla yıkım emri verilmiş olan bu tekkenin II. Beyazid vakıflarından olduğu tutanaklarda belirtilmiştir. ${ }^{60}$ Mehmed Efendi tekkesi ve binası yıkılmış, türbesi yıkılmamıştır. Etrafı taş duvarla çevrilip yıkıldığı belirtilen belgede yıkım sonrası kalan 390 zirâ arsanın müzayede ile 400 kuruşa Nuri adında bir kişiye satıldığı belirtilir. ${ }^{61}$

Tekkenin yeniden canlandırılması el-Hac Mehmed Perişan Baba (ö. 1866) döneminde gerçekleştirilmiştir. ${ }^{62}$ Halefi olan Seyyid Hafız Mustafa Baba ise tekkenin büyümesi ve daha aktif olmasında daha da etkili olmuştur. Seyyid Hafız Mustafa Baba tekkeye 1000 kuruş ve bir menzil vakfederek türbedarlığına getirilmiş, bundan sonra da tekke 1925 'te kapatılmasına kadar faaliyetlerini sürdürmüştür. ${ }^{63}$ Baha Tanman'ın tekkenin mimarisi hakkında yaptığı ayrıntılı çalışmasında göstermiş olduğu konak fotoğrafı ve planın Seyyid Hafız Mustafa Baba’nın vakfettiği menzile ait olması muhtemeldir. ${ }^{64}$ Seyyid Hafız Mustafa Baba'dan sonra türbedarlığa getirilmiş bizim tespit edebildiğimiz şeyhler tevcih tarihleri ile şöyledir: Hacı İbrahim (20 Muharrem1293/16 Şubat 1876), Hafız Mehmed Nureddin Efendi bin Hasan (24 Şaban 1316/7 Ocak 1899), Hacı Hamdi Efendi (2 Receb 1321/24 Eylül 1903). ${ }^{65}$

\section{Şehidlik Tekkesi}

Mahmud Baba tekkesi olarak da bilinen bu tekke, Rumelihisarı'ndaki Şehitlik bölgesindedir. Bugün Boğaziçi Üniversitesi'nin sınırları içerisinde bulunmaktadır. Bilinen en eski postnişini Ali Baba'dır (ö. 1771). Mezar taşında 'tarik-i abdalandan Ali Baba şeklinde kayıt vardır. ${ }^{66} 18$. yüzyıl sonunda dahi Ali Baba’nın bir Rum Abdalı olarak anılması ilgi çekicidir. Bu tekke, Bektaşi tarikatının Rum Abdallarının mirası üzerinde oluştuğu tezinin doğruluğunu bize gösterir. Kuruluş

60 BOA, MAD 9371, no. 406 (1242/1826).

61 BOA, MAD 9371, no. 406 (1242/1826).

62 Mezar taşındaki yazının çevirisi ve görüntüsü için bkz. Vatin ve Zarcone, "Le tekke bektachi de Kazlıçeşme,” s. 90-91.

63 EV.MKT.CHT 402, no. 145.

64 Baha Tanman, "Le tekke Bektachi de Kazlıçeşme; II. Emplacement, Architecture et Décoration," Anatolia Moderna- Yeni Anadolu VII (1997), s. 111-126.

65 EV.MKT.CHT 402, no.145; EV. MKT.CHT 697 (1261/1845), no. 215; EV.MKT. 782, no. 135 (1265/1849); VGM 887, no. 244; VGM 892, no. 108.

66 Işın, "Bektaşilik,” s. 133. 
tarihine dair birçok rivayet bulunmasına rağmen tam olarak ne zaman kurulmuş olduğu tespit edilememiş bir tekkedir.

Bu rivayetler Şehidlik bölgesinin tarihçesi ile de örtüşmektedir. İstanbul'un fethinden önce fetih lojistiği ve altyapısının oluşturulabilmesi için Sultan II. Mehmed 1452 yılında üç bin kadar işçi ve usta ile bu bölgede Rumelihisarı'nı yaptırmıştı. Bir inanışa göre, Osmanlı işçi ve askerleriyle yerli halkın çatışmalarında ölenler Şehidlik tekkesi mezarlığına defnedilmiştir. Evliya Çelebi'ye göre ise bu definler hisarın inşasından önce Osmanlıya ait olan bu bölgede bulunan bağlardan izinsiz üzüm yiyen Rumlarla bağcılar arasındaki çatışmalar sonucu olmuştur. Bir diğer rağbet gören rivayet ise mezarlı̆̆ın fetih esnasında ölen şehidler için oluşturulduğudur ki bu da tekkenin kuruluşunu fetihle ilişkilendiren bir kanıdır. ${ }^{67}$

Bu tekkenin İstanbul'un fethinden önce burada Rumelihisarı yapılırken kurulmuş olduğuna dair bir görüş vardır. Belgelerle desteklenmiş olmamasına rağmen tekke mezarlığında bulunan altı mezar taşı fetih dönemi ve öncesi tarihleri işaret eder ki bunlardan bir tanesi de 855/1451'de vefat etmiş Şeyh Bedreddin isimli bir dervişe aittir. Bu dervişin meşhur Akşemseddin'in müridlerinden ve İstanbul'un alınması için Fatih Sultan Mehmed'e eşlik edenlerden olduğu düşünülmektedir ${ }^{68}$ Fakat Edhem Eldem'in mezar taşları üzerinde yaptığı derin çalışma bu taşın 19. yüzyılda yapılmış olduğunu ispatlamıştır. Eldem, Şeyh Bedreddin için böyle bir mezar taşının yaptırılmış olmasını bir geleneği icat etme çabası olarak yorumlar. ${ }^{69}$

Tekke hakkında 16. ve 17. yüzyıllara ait hiçbir belge ve bilgi yoktur. Evliya Çelebi'nin Seyahatnamésinde de bahsi geçmemektedir. Bu döneme ait mezar taşları tekke mezarlığında tespit edilememiştir. Tekke ile ilgili belgelerin 18. yüzyıl sonlarına ait olması bir muamma oluşturuyorsa da o tarihe kadar henüz kurulmamış olduğunu düşünmemek gerekir. Kapatılma kayıtlarına düşülen bir nota göre tıpkı Karaağaç ve Mehmed Efendi tekkeleri gibi II. Bayezid vakıflarından kabul edilerek işlem görmüştür. ${ }^{70} \mathrm{Bu}$ ise tekkenin kadim tekkelerden olduğunu düşünmemize yol açmaktadır.

67 Günay Kut ve Edhem Eldem, Rumelihisarı Şehidlik Dergahı Mezar Taşları (İstanbul: Boğaziçi Üniversitesi Yayınevi, 2010), s. 15-19.

68 Zarcone, "Les couvents Bektachis d'Istanbul," s. 207.

69 Edhem Eldem, Death in Istanbul: Death and Its Ritual in Ottoman-Islamic Culture (İstanbul: Ottoman Bank Archives and Research Centre, 2005), s. 156; Kut ve Eldem, Rumelihisarı ve Şehidlik Dergahi, s. 25-30.

70 VGM 577, no. 33 (1331/1913) 
Tekkenin bilinen şeyhleri mezar taşlarının incelenmesi sonucu, Derviş Ali Baba (ö. 1766-67), Mustafa Baba (ö. 1770-71) ardından kardeşi Ahmed Baba (ö. 1783-84), ve Mahmud Baba (ö. 1860-61) olarak, büyük bir olasılıkla sunulmuştur. ${ }^{71} 1826$ 'da dergâhın kapatılması Şeyh Mahmud Baba'nın meşihat dönemidir. Mahmud Baba yıkım esnasında Kayseri'ye sürülmüştür. ${ }^{72}$ Tekkenin olduğu bölge ve beş odalı hareme mahsus bir ev de yıkılmıştır. Yıkım tutanağında geçen bilgiye göre bunun haricinde Sultan Bayezid vakfına ait olan Rumelihisarı'nın arka taraflarına doğru uzanan 88 dönüm bağ ve tarlayı tekke şeyhi satın almıştır. Bunun on dönüm miktarı tekkeye vakfedilmiş ve zaviyedarlığı da evlad-1 evlada şart kılınmıştır.

\section{Durmuş Dede Tekkesi}

Kadim tekkelerden kabul edebileceğimiz sonuncu tekke ise idari olarak Galata'ya tâbi, Rumelihisarı'nda olduğu bilinen ve 17. yüzyıla kadar mevcudiyetini ispat edebildiğimiz Durmuş Dede tekkesidir. Evliya Çelebi Rumelihisarı'nın kıble yönünde dedenin büyük bir asitanesi olduğunu söyler ve 'Fukara-yı Bektaşiyandan türbedarların ve çerag ve tabl-1 kudümleri ile araste bir nazargahtır' diye tarif eder. Evliya, Durmuş Dede'nin Karadenizi Tuna’ya bağlayan Akkirman'dan olduğunu gençliğinde İstanbul'a getirtilip Rumelihisarı'nda çalıştığını söyler. Burada kerametleriyle birçok gemiye yardım ettiğine inanılır. ${ }^{73}$ Rumelihisarı'ndaki bu tekkeye tespit edebildiğimiz en eski atama 1084/1673 senesinde yapılmıştır. ${ }^{74}$ Tekke, hisar ile sahil tarafında Kayalar mezarlığı arasındadır. ${ }^{75}$ Bir diğer kaynak ise onu Gülşeni tarikatından kabul etmiştir. ${ }^{76}$ Günümüz araştırmacıları da Gülşeni tarikatından Şeyh Hasan Zarifi Efendi (ö. 1569) tarafindan kurulduğu ve 18. yüzyıl ortalarında Halveti-Cerrahi tarikatına geçmiş olduğunu belirtmektedir. ${ }^{77}$

71 Kut ve Eldem, Rumelihisarı ve Şehidlik Dergahı, s. 40.

72 Mesut Ayar, Bektaşilikte Son Nefes, s. 43.

73 Evliya Çelebi, Evliya Çelebi Seyahatnamesi: Topkapı Sarayı Bă̆dat 304 Yazmasının Transkripsiyonu-Dizini, der. Zekeriya Kurşun, Seyit Ali Kahraman, Yücel Dağlı, c. 1 (Istanbul: Yapı Kredi Yayınları, 1999), s. 196. (Bundan sonra Evliya Çelebi Seyahatnamesi)

74 VGM 438, no. 64.

75 Baha Tanman, “Durmuş Dede Tekkesi,” Dünden Bugüne İstanbul Ansiklopedisi, III, 106-7. 76 Ayvansarayi Hüseyin Efendi, Hadikatül-Cevami, c. 2 (İstanbul: Matbaa-i Amire, 1281), s. 126.

77 Tanman, “Durmuş Dede Tekkesi,” s. 106; Fatih Köse, İstanbul Halvetî Tekkeleri (İstanbul: Marmara İlahiyat Fakültesi Yayınları, 2012), s. 112-115. 
Vakfın vakfiyesi kayıptır. 1894'te zaviyedarlığına atanmış olan Mehmed Eşref Efendi, atamadan bir sene sonra arzuhal ile II. Mahmud zamanında vakfın icare bedelinden Durmuş Dede evkafının gelir bedelinin ne olduğunun tespitini istemiş, fakat dönemin Senedat İdaresi, defter derkenarlarını araştırdığını ve vakfiyesinin kayıtlarda bulunmadığını belirtmiştir. ${ }^{78}$

\section{Şahkulu Sultan Tekkesi}

Üsküdar Merdivenköy'deki Şahkulu Sultan Dergâhı bilinen en eski dergâhlardan bir tanesidir. Kayıtlarda Nerdibanlı köyü olarak geçmektedir. Paul Dumont ve Béatrice Saint Laurent' in dikkat çektiği üzere Şahkulu Sultan tekkesi tıpkı Rumelihisarı'ndaki Şehidlik ve Eyüp’teki Karyağdı baba tekkeleri ve hatta Balkanlar'daki diğer Bektaşi tekkeleri gibi doğanın içine kurulmuş bir tekkedir. Şahkulu tekkesinin yansıttığı bir diğer özellik ise Bizans kültlerinin olduğu yerlere yerleşmiş ve zirai faaliyetleri ile manastır hayatını andıran bir yaşamı bu tekkelerde kurmuş olmasıdır. ${ }^{79}$ Bu dergâhın İstanbul'un fethine veya daha önceki kuşatmalarına katıldığı söylenen Horasan Erenlerinden Şah Sultan'a ait olduğu rivayet edilmektedir. Gene Horasan'dan Anadolu'ya yolculuğu esnasında kendisine eşlik ettiğine inanılan Sancaktar Baba, Gözcü Baba, Yörük Baba, Mah Baba ve Gül Baba, Şahkulu Sultan zaviyesi arazisinde defnolunmuştur.

Bazı Osmanlı tarihçileri Şahkulu’nun II. Bayezid dönemine rastlayan 1511'deki Şah İsmail taraftarı bir ayaklanmanın lideri olduğunu düşünmektedir. Bu tekkede bulunan mezar taşlarındaki bilgilerden yola çıkarak tekkenin bilinen en eski babası Mustafa Baba’dır (ö. 1682). Diğerleri Yusuf Baba (ö. 1685), Mürşid Ali Baba (ö. 1697), Hacı Feyzullah Efendi (ö. 1761), Mahmut Baba (ö. 1793), İsmail Baba (ö. 1796), Ali Baba (ö. 1813), Ahir Mehmet Baba (ö. 1850)..$^{80}$ Tekkeye bağlı Şahkulu ve Abaza Çavuş 17. yüzyılın önemli dervişlerindendir. Abaza Çavuş Sultan Ahmed'in hizmetinde çavuşluk ve ulaklık yapmış bir veli olup türbesi bu tekkede

78 BOA, EV.MKT 2201, no. 49 (1311/1894); BOA, EV.MKT 2201, no. 50 (1311/1984).

79 Paul Dumont ve Béatrice Saint Laurent, "Le complexe du tekke Bektaşi de Merdivenköy," Anatolia Moderna II (1991), s. 76-77.

80 Burhan Kocadağ, Şahkulu Sultan Dergahı ve İstanbul Bektaşi Tekkeleri (İstanbul: Can Yayınları, 1994), 44-45; Şahkulu Sultan tekkesine ait mezarlık üzerine yapılmış ayrıntılı çalışma için bknz. Jean-Louis Bacqué-Grammont, "Contribution à l'étude des cimetières: Note sur la typologie des stèles," Anatolia Moderna II (1991), s. 44-47. 
bulunmaktaydı. ${ }^{81}$ Bu iki dervişin kabrinin Şahkulu tekkesinde bulunması 18. ve 19. yüzyıllarda tekkeye çok yoğun bir ziyaretçi akınının doğmasına yol açmıştır. ${ }^{82}$ Tekkeyi ziyareti sırasında vefat edip tekke mezarlığına gömülen kişilerin mezar taşları göstermiştir ki tekke çoğunlukla Anadolu'dan, Trakya’nın doğusundan, Sırbistan, Makedonya, Yunanistan ve Arnavutluk'tan ziyaretçiler almıştır. ${ }^{83}$ Tekke mezarlığında yapılmış olan prosopografik çalışma sonucunda ortaya çıkan üst rütbeli (ağa, bey ve efendi gibi) birçok kişinin tekke ile ilişkili olduğu ortaya çıkmıştır. Ancak mezar taşları çoğunlukla 19. ve 20. yüzyıllara ait olup daha önceki dönemlerden günümüze ulaşmış olanlar çok daha azdır. ${ }^{84}$ Tekke Ahir Mehmed Baba’nın meşihat döneminde, Yeniçeri Ocağı’nın ortadan kaldırılmasıyla birlikte kapatılmış ancak kısa bir süre sonra Ali Baba (ö. 1849) tarafından ikinci defa kurulmuştur.

Yeniçeri Ocağı' nın kapatılmasından sonra durgun bir döneme girmiş olan dergâhı yeniden canlandırmak amacıyla Mehmet Hilmi Dede Baba harekete geçer ki buna yeni bir vakıf kurulması da dahildir. 1331/1913 tarihinde kaydedilen vakfiyesine göre Sancaktar baba, Gözcü Baba, Yörük Baba, Mah Baba ve Gül Baba’nın kabirlerinin bulunduğu vakfa ait araziler zaman içerisinde gasp edilmiş ve zaviyenin kontrolü dışında kalmıştır. Bu sebeple Mehmet Ali Hilmi Dede Baba gasp edilen araziden satılanların değeri neyse alıp zaviyeye tekrardan katabilmek için bir takım emlak ve arazilerini vakfetmiştir. Bu canlandırma sonucunda bir dizi ev, bahçe ve işyeri açllmış, genişletilen arazilerde sebze, meyve ve ipek böceği yetiştirilmiştir. ${ }^{85}$ Günümüze kadar ulaşmış binaların bulunduğu geniş arazisi ve meydan evi ile İstanbul'un en ilgi çekici dergâhlarından biridir. ${ }^{86}$ 1826 'da bu dergâhın şeyhinin oturduğu bina hariç tüm binalarının yıkıldığı göz önüne alınacak olursa bu meydan evi Mehmet Ali Hilmi Dede Baba zamanında yaptırılmış olabilir.

81 Lucy Mary Jane Garnett, Osmanlı Toplumunda Dervişler ve Abdallar (İstanbul: Dergah Yayınları, 2010), s. 71.

82 Raymond Lifchez, “The Lodges of Istanbul," der. Raymond Lifchez The Dervish Lodge: Architecture, Art, and Sufism in Ottoman Turkey içinde (Berkeley, Los Angeles, Oxford: University of California Press, 1992), s. 117.

83 Thierry Zarcone, "Merdivenköy el la géographie bektachie de l'Empire ottoman,” Anatolia Moderna II (1991), s. 37-38.

84 Jean-Louis Bacqué-Grammont, H.P Laqueur ve Nicolas Vatin, "Corpus de Stalae Turcicae V," Anatolia Moderna II (1991), s. 129.

85 VGM 577, no. 33 (1331/1913)

86 Mimari değerlendirmesi için bkz. Lifchez, “The Lodges of Istanbul,” s. 73-130. 


\section{Karaca Ahmed Sultan Tekkesi}

Karaca Ahmed Sultan Tekkesi Üsküdar'dadır. Eski tekkelerden olup Evliya Çelebi'nin Seyahatnamésinde yerini almıştır. Tekkede medfun olan Asmani Dede tarik-i Yesevi'den olarak tarif edilmiştir. Asmana bakıp söylediklerinin çıktığı rivayet edilir. Yavuz Sultan Selim, İran seferine çıarken Sultan Gavri ile çatışıp kazanacağını öngörmesi ile ün salmıştır. ${ }^{87}$ Tekkenin sözlü geleneğinde ise Karaca Ahmed Sultan'ın Orhan Bey zamanında Bizans'a karşı savaşmış Horasan erenlerinden olduğu kabul edilmektedir. ${ }^{88}$ Türbenin mezarlığında atının mezarının bulunduğu iddiası ise göçebe Türk-Moğol kültürünün tekke geleneğindeki tesirini gösterir. ${ }^{89}$

Bu kuruluş rivayeti ile Karaca Ahmed Sultan tekkesinde de başka tekkelerde gördüğümüz "gelenek icadına" gidildiğini görüyoruz. Şu zamana kadar bahsettiğimiz tekkelerin hemen hepsi bir şekilde İstanbul'un fethiyle tarihini ilişkilendirmiştir. Dahası fetih esnasında İstanbul'da bulunan Horasan erenleri, Rum Abdalları veya Yesevi dervişlerini kurucu şeyh kabul etmiştir. Böyle bir geçmişi benimsemek tekkeye kutsiyet ve meşruiyet kazandırmaktadır. Oysa son yapılan çalışmalar Bektaşi tarikatının bu tariklerin şeyhlerini sonradan kendisine silsile olarak kabul etmiş olduğunu bize göstermektedir. İstanbul'daki tekkelerin de tarikatın genelinde görülen bu yönelimi takip ettiği söylenebilir.

Karaca Ahmed Sultan'ın Üsküdar'daki türbesi Gülfem Hatun (ö. 1561) tarafından yaptırılmıştır. ${ }^{90} 19$. yüzyıla ait bir arşiv belgesinde ise Karaca Ahmed Sultan zaviyesi ve türbesinin Atik Valide Sultan evkafından olduğu açıç̧a belirtilmiştir. ${ }^{91}$ Atik Valide Sultan, III. Murad'ın annesi Nurbanu Valide Sultan'dır (1525-1583). Nurbanu Valide Sultan 1570-79 yılları arasında Mimar Sinan’a Üsküdar'da bir külliye yaptırmış, bu külliyenin vakfiyesi 1582 tarihinde düzenlenmiştir. Nurbanu Sultan bundan bir sene sonra vefat etmiştir. ${ }^{92}$ Nurbanu Atik Valide Sultan vakfi üzerine yapılmış bir

87 Evliya Çelebi Seyahatnamesi, I, s. 205.

88 Mehmet Yaman, Büyük Türk Akıncısı-Evliyası-Hekimi Karaca Ahmed Sultan Hazretleri

(İstanbul: Karaca Ahmed Sultan Türbesini Koruma Derneği Yayınları, 1989), s. 15-16.

89 Yaman, Türk Akıncısı, s. 86-87.

90 Yaman, Türk Akıncısı, s. 77.

91 BOA. EV.MKT.CHT 445, no. 14 (1315/1898).

92 Nurbanu Sultan ve Atik Valide Sultan Külliyesi hakkında ayrıntılı bilgi için bkz.: Nina Ergin, "Taking Care of Imarets: Repairs and Renovations to the Atik Valde Imareti Istanbul, circa 1600-1700," der. Nina Ergin, Christoph K. Neumann, Amy Singer, Feeding People, Feeding Power: Imarets in the Ottoman Empire içinde (İstanbul: Eren 
yüksek lisans tezi vakfin 998/1589-90, 1007/1598-99 ve 1080/1669-70 tarihli muhasebe defterlerindeki gelir ve giderleri ayrıntılı bir şekilde değerlendirmiştir. Ancak gerek vakfiyede gerekse muhasebe defterlerinde Karaca Ahmed Sultan zaviyesi adı zikredilmemektedir. ${ }^{93}$ Karaca Ahmed Sultan türbe ve zaviyesine bir nakit aktarımı tespit edilememiş olmakla beraber elimizdeki belgeler bizi bu tekkenin 16. yüzyılın ikinci yarısında bir vakıf haline geldiğini. III. Murad'ın kadın akrabaları tarafından ihya edildiğini söylemeye izin vermektedir. Zira türbenin iç kapısındaki bir kitabede gene III. Muradın yakınlarından bir kadının 1594'te Karaca Ahmed Sultan tekkesi ve türbesini onarıp kitabenin yazılı olduğu kapıyı yaptırdığı yazılmıştır. ${ }^{94}$

Karaca Ahmet Sultan tekkesinin Yeniçeri Ocağı'nın kapatıldığı sırada herhangi bir muameleye uğradığına dair bir kanıt yoktur. Ne kapatma, ne sürgün, ne de şeyhliğine Nakşibendi şeyhlerinden birinin atandığına dair bir belge görülmemiştir. Tekkenin bu dönemde de faaliyetine devam ettiği anlaşılıyor.

İstanbul'daki Bektaşi tekkeleri hakkında çok nadir olarak ekonomik faaliyetlerini yansıtan belgeler de bulunmaktadır. 1857 yılının Haziran ayına ait bir belge bu açıdan oldukça değerlidir. Belge Karaca Ahmed Sultan vakfı mülkünden olan ve türbe arazisi içinde bulunan bir taş dükkânı hakkındadır. 40 akçe kira bedeli olan bu dükkânın gediği Hacı Mehmed b. Mustafa'ya aittir. Vefatından sonra gedik hakkının dört oğlundan birine verilmesi için yapılan başvuru kabul edilmiştir. Tekkenin diğer kaynaklarını bilmemekle beraber sınırları içerisinde mevcut dükkânın işletildiğini buradan öğreniyoruz. ${ }^{95}$ Tekkeye ait başka dükkânlar olup olmadığını bilmiyoruz, fakat türbenin civarında Üsküdar ahalisinin işlettiği dükkânların olduğunu göz önünde bulundurursak tekkenin halkın kiraladığı başka dükkânlarının da olma ihtimali vardır. ${ }^{96}$ Bir diğer gelir kaynağı olarak türbenin civarındaki kabristanın koruculuğu görevi görünmektedir. ${ }^{97}$

Yayınları, 2007), s. 151-167; Pınar Kayaalp-Aktan, "The Endowment Deed of the Atik Valide Mosque Complex: A Textual Analysis," Feeding People, Feeding Power: Imarets in the Ottoman Empire, s. 261-273; Ömer Düzbakar, "Charitable Women and Their Pious Foundations in the Ottoman Empire: The Hospital of the Senior Mother, Nurbanu Valide Sultan," JISHIM 5 (2006), s. 11-20.

93 Tijen Sabırlı, Vakfiyesi ve Muhasebe Kayıtları Işı̆̆̆nda Nurbanu Atik Valide Sultan Vakfı, yayınlanmamış Yüksek Lisans Tezi (İstanbul Üniversitesi, 2012), özellikle s. 59-82.

94 Sabırlı, Atik Valide, s. 82-83.

95 BOA, EV.MH 644, no. 83 (1273/1857).

96 BOA, EV.MKT 120, no. 173 (1277/1860).

97 BOA, EV.MKT.CHT 598, no. 64 (1260/1844). 


\section{Yarımca Baba Tekkesi}

Gene Üsküdar'da bir diğer önemli tekke Öküz Limanı veya Paşa limanı bölgesindeki Yarımca Baba tekkesidir. Kurucusu olan Yarımca Baba’nın hayatı veya ne zaman yaşadığı bilinmemektedir. Fakat tespit ettiğimiz 'kuyud-u vakfiye' kaydı düşülen bir belgede "kuyud 1027/1617-18" ibaresi geçmektedir. Bu da Yarımca Baba tekkesi vakfının ilk bu tarihte kayda girildiğini düşündürmektedir. ${ }^{98}$ Tekkenin arşiv belgelerinde Paşa Limanı, Yarımca Baba, Yarımcabaş Baba veya Kelleci Bali Tekkesi olarak geçtiği tespit edilmiştir.

Ilıca deresinin yakınlarında olduğu beyan edilir. ${ }^{99}$ Evliya Çelebi bu tekkeyi Öküz Limanında Kaya Sultan yalısı dibinde küçük bir asitane olarak anlatmıştır. ${ }^{100}$ Tekke 1826 'da kapatılmış o dönemde meşihatı sürdüren Ahmed Baba müridleri ile birlikte Hadim'e sürülmüştür. Daha sonra tekke Nakşibendi ve Kadiri ayinlerinin yapıldığı bir dergâh olarak açık tutulmuştur. Bu dönemde kendilerine tahsis olunan taamiyelerle geçinemeyecek durumda olduklarını ve 100 guruş taamiyenin arttırılmasını isteyen arzuhallerinden dergâhın ekonomik olarak da sıkıntılı bir süreçten geçtiği düşünülebilir. ${ }^{101} \mathrm{Bu}$ istek üzerine tekkeye Hamidiye imaretinden fodula bağlanmıştır. ${ }^{102}$ Bir keşif defterine göre, gene bu dönem içerisinde tamirat gördüğü ve bu esnada camisinin de onarıldığı belirtilmektedir. ${ }^{103} \mathrm{Bu}$ cami hakkında bir bilgi bulunmamakla beraber 1826 'dan sonra yaptırılmış olması muhtemeldir. Bu tekke ile ilgili tespit edebildiğimiz bir diğer önemli bilgi ise 1873/1290 yılında Ocak-1 mülga vakfından, yani kaldırılmış Yeniçeri Ocağı'nın vakfından ferağen bir araziden 24 kuruş gelir aldığıdır. ${ }^{104}$ Bu belge değişik vakıflara ferağ edilmiş malların bir listesidir. Bu tip tek sayfalık vesikalar Evkaf kalemine ait arşivde sıkça karşımıza çıkmaktadır. Belge bu tekkenin mülga Yeniçeri Ocağı ile bağının olduğunu gösterse de bunun boyutları hakkında bize yeterli bir bilgi vermekten uzaktır. Mülga ocak vakfının mallarına el konulduğunu ve bunların Asâkir-i Mansûre-i Muhammediyye ordusunu finanse etmek için kullanıldığını biliyoruz.

98 BOA, EV.MKT.EVM 38, no. 123 (1330/1912)

99 BOA, EV. MKT. EVM 38, no. 122 (1330/1912); BOA, EV.MKT.EVM, no. 123

(1330/1912); BOA, EV.MKT. EVM, no. 127 (1330/1912); BOA, EV. MKT.EVM, no.

$132(1330 / 1912)$.

100 Evliya Çelebi Seyahatnamesi, c. 1, s. 203.

101 BOA, EV.THR 129, no. 9 (1257/1841).

102 BOA, EV.BKB 106, no. 100 (1257/1841).

103 BOA, EV.MH 64, no. 120 (1257/1841).

104 BOA, EV.MH 2409 no. 89 (1290/1873). 
Bu el koyma esnasında bazı malların vakıflara intikal ettirildiği düşünülebilir. Zira başka evraklarda da kurum veya kişi vakıflarının bu mülga vakıf arazilerinden ferağen bedel aldığı arşiv belgeleri arasındadır.

\section{Müsliman Dede Zaviyesi}

İbrahim Paşa nahiyesinde Balaban Ağa mahallesinde kurulmuş küçük bir Bektaşi zaviyesidir. Vakfiyesinde zaviyeye bitişik olan iki tahtani bir fevkani evi Müsliman Dede kendine vakfetmiş daha sonra da Hacı Bektaş oğlu Mahmud'a ve daha sonra onun oğullarına kalmasını istemiştir. Ancak bu oğullar tükendikten sonra mülkünün Hacı Bektaş Ocağı'na kalması kaydedilmiştir. ${ }^{105}$ Buradan anlaşılıyor ki, vakfedilen konut aslında bir kişisel mülk olarak geçmekte tekkenin mülkü olmamaktadır. Faroqhi bu tip kişiselleştirilmiş vakıf mülklerine bir örnek de Ankara’dan göstermiştir. ${ }^{106}$ Bunu, II. Bayezid dönemi tarikat teşkilatının merkezileştirilmesi ekseninde düşünecek olursak, mülk gelirlerini Kırşehir'deki merkezden ziyade kendi bünyelerinde tutabilmeleri için geliştirilmiş bir yöntem olarak görmek mümkündür. Belirtildiği üzere kapatılma esnasında el konan tekke mülkleri ise diğer tekke vakıflarından ayrı tutulmuş ve onların mülkleri mîrî tarafından zapt edilmiştir. ${ }^{107}$

Bazı hallerde vakfedilen ve sonradan Hacı Bektaş ocağına bırakılacağı şart koşulan mülklerin bir zaviye ile ilgisi bulunmamaktadır. Örneğin Aksaray çarşısı civarında bulunan Derviş İvaz b. İlyas vakıf olarak bir ev, bir ahır ve muhteviyatı ve iki dükkânı önce evladına sonra Hacı Bektaş’n oğlu Mahmud Çelebi ve onun evladına bırakmış, nihayetinde de Hacı Bektaş ocağına vakfetmiştir. Vakfiye 891 tarihli olup 1009/1600 yılında halen Hacı Bektaş ocağına devretmemiş ve İstanbul vakıf tahrir kayıtlarına geçmiştir. ${ }^{108} \mathrm{Bu}$ bir çeşit hayır amaçlı da olabilir. Bu tip kısa soluklu ve zaviyesi olmayan vakıfların arşiv belgelerine yansımamış olmasına rağmen örneklerinin daha fazla olduğu düşünülebilir.

Büyük ve kadim Bektaşi tekkelerinin yanı sıra İstanbul'da başka Bektaşi tekkelerinin de bulunduğu belgelere yansımaktadır; ancak bunlar hakkında yeterli

105 Ömer Lütfi Barkan ve Ekrem Hakkı Ayverdi, İstanbul Vakıfları Tahrir Defteri 953 (1546) Tarihli (İstanbul: Baha Matbaası, 1970), s. 153.

106 Faroqhi, "The Tekke of Hacı Bektaş," s. 192.

107 BOA, HAT 293, no. 17453 (1241/1826)

108 Mehmet Canatar, Istanbul Vakıfları Tahrir Defteri: 1009 (1600) Tarihli (İstanbul: İstanbul Fetih Cemiyeti, 2004), s. 506. 
bilgi yoktur. Arşiv çalışmalarımızdan tespit edebildiğimiz tekkeler Bandırmalızade Haşim Efendi Tekkesi ve Şeyh Ahmed Kartal zaviyesidir. Bunlardan özellikle Kartal Baba tekkesi literatürde varlığı kayda geçmemiş bir tekkedir. Belgeler en erken 18. yüzyıla kadar gidiyor olmasına rağmen daha erken dönemde kurulmuş olma olasıl lğı yüksektir. VGM Arşivlerinden tespit ettiğimize göre bu tekke Üsküdar Pazarbaşı'nda bulunmaktadır. Aynı mahalde bulunan Kıncı Baba tekkesinin aksine 1826 'dan sonra da faaliyetine devam etmiştir. ${ }^{109}$ Bandırmalızade Haşim Efendi'nin (1718-1782) Bektaşi tekkesi de Yeniçeri Ocağı kaldırıldıktan sonra varlığına devam etmiş bir tekkedir, fakat kurduğu zaviye kısa bir süre sonra Celvetiye tarikatına katılmışıı. ${ }^{110}$

\section{Mürüvvet Baba Tekkesi}

Önemli görülen bir diğer tekke ise Üsküdar'da Kasım Ağa mahallesinde bulunan Mürüvvet Baba tekkesidir. Ne zaman kurulduğuna dair hiçbir veriye ulaşamadığımız bu tekkenin kapatılışı hakkında daha fazla bilgiye sahibiz. Tekke 1826'da birçoğu gibi kapatılmış Şeyhi Mustafa Baba Tire’ye sürülmüştür. ${ }^{111}$ Kapatıldığı esnada arazi olarak büyüklüğü 3368 zirâ (yaklaşık 2 dönümdür). ${ }^{112}$ Derviş Mustafa Baba’nın Üsküdar'da Eski Valide'de Arakiyeci el-Hac Mehmed mahallesinde bir kapı ağası bostanı gediği vardır ve yıkım esnasında bu bostana ve içindeki eşyalara da el konulmuştur. Bostandaki meyvesi ve bir bargirinin Seyyid Halil efendiye devredildiği belgede belirtilmiştir. Bu ürünün değeri 500 kuruştur. Dolayısıyla çok da büyük bir bostan olduğunu düşünmemek gerekir. ${ }^{113}$

Gene bir önemli belge Hasluck'un Istıranca'da olduğunu iddia ettiği bir Bektaşi tekkesi hakkındadır. Evliya Çelebi bu tekkeden bahsederken "Istıranca dağlarında bir oda yeniçeri avcıları ile beraber bir asitane-i bektaşiyan da vardır" der. ${ }^{114} \mathrm{Bu}$ tekke hakkında hiçbir belgeye ulaşılamamasından ötürü tarihçiler bu tekkenin varlığına halen şüpheyle yaklaşmaktaydılar. Araştırmamız sırasında bu tekkenin varlığını ispatlayan bir belgeye ulaşılmıştır. Belge tekke postnişini derviş

109 BOA, EV. MH 2084, no. 375 (1296/1879); BOA, EV.MKT 3182, no. 119 (1323/1906).

110 Kamil Yılmaz, Aziz Mahmud Hüdayi ve Celvetiye Tarikatı (İstanbul: Marmara Üniversitesi, 1980), s. 242-45.

111 Ayar, Bektaşilikte Son Nefes, s. 43.

112 BOA, MAD 9731 (1242/1826).

113 BOA, EV. D 38565, no. 836 (1257/1842).

114 Evliya Çelebi Seyahatnamesi, c. 1, s. 485. 
Hasan'ın bir başka derviş ile olan husumetinin kayıtlara yansıması üzerinedir. ${ }^{115}$ 1174/1760 tarihli bu belge bize Istıranca dağlarında bulunan Çatalca kazasının Özili(?) karyesinde Durbalı(?) ismiyle tanınmış bir Bektaşi tekkesinin varlığını tesciller. ${ }^{116}$ Tabii kuruluşunun bu tarihten daha öncelere dayandığı aşikardır. Bu bölge civarında bulunmuş bir Bektaşi mezar taşı Ağlamış Ahmed Baba'ya $(1240 / 1824-25)$ aittir. ${ }^{117}$

\section{Sonradan Kurulmuş Tekkeler}

\section{Karyağdı Baba Tekkesi}

Eyüp’te İdris Köşkü civarındaki Karyağdı Baba Tekkesi, eski İstanbul tekkelerindendir. İdris Köşkü, Evliya Çelebi’den öğrendiğimiz kadarıyla Bayramiye tarikatından Şeyh İdris tarafından yapılmıştı. ${ }^{118}$ Günümüzde tekke İdris Köşkü mevkiinde Karyağdı Sokağı ile Ballı Baba Sokağı’nın (eski adı Bali Baba) birleştiği yerdedir. Piyer Loti kahvesinin biraz ilerisinde olup alt tarafinda 1624 senesinde yıktırılmış Dolancı Derviş Mehmed Efendi Mevlevihanesi, yukarı tarafında da büyük kar kuyuları bulunmaktayd. ${ }^{119}$ Eyüp mahallesinin en yüksek tepesinde yerleşim alanlarından uzak bir tekkedir.

Karyağdı Baba Tekkesinin Hadikatül-Cevami'de kurucu şeyhi es-Seyyid Mehmed Ali Baba’nın İstanbul fethine katılmış Horasan erenlerinden olduğu söylenmiştir. Hâlâ tekke kabristanında bulunan mezar taşında Horasani elifi tac

115 VGM 2381, no. 46 (1174/1760).

116 Prof. Machiel Kiel bir başka Durbalı Sultan Tekkesi'nin Yunanistan'ın Teselya şehrinin doğusunda kalan Çatalca kasabasında bulunduğunu Osmanlı arşiv belgelerinden tespit etmiştir. Bu tekke ile bizim tespit ettiğimiz Istıranca dağlarında bulunan tekkenin ilişkisi bilinmemektedir. Machiel Kiel, "Durbalı Sultan Resurrected?: Some Remarks on Recent Developments Around the Bektashi Tekke of Durbalı Sultan near Pharsala-Thessaly/Durbalı Sultan Yeniden Ortaya mı Çıkıyor?: Tesali Yakınındaki Bektaşi Tekkesi Durbalı Sultan Civarındaki Son Gelişmeler Üzerine Bazı Açıklamalar,” Türk Kültürü ve Hacı Bektaş Veli Araştırma Dergisi 52 (2009), s. 53.

117 Bilgin Turnalı, Esin Yücel "Ağlamış Baba," Istanbul Kültür ve Sanat Ansiklopedisi I, s. 329-30.

118 Evliya Çelebi Seyahatnamesi, I, s. 170; Şeyh İdris hakkında ayrıntılı bilgi için bkz. Nihat Azamat, "İdrîs-i Muhtefî," DİA, 21 (2000), s. 489-91.

119 Mehmet Nermi Haskan, Eyüp Tarihi (İstanbul: Türk Turing Turizm İşletmeciliği Vakfı Yayınlar1, 1993), s. 128-29. 
bulunmaktadır. ${ }^{120}$ Fakat, günümüzde kabul edilen vefat tarihi 1544 'tür. ${ }^{121}$ Burada Istanbul'un fethine gelen Horasan erenlerinin bir "gelenek icadı" olarak tekrardan karşımıza çıktığı görülmektedir.

Karyağdı Baba tekkesinin bilinen postnişinleri arasında Horasani Karyağdı Ali Baba'dan sonra Bosnevi Derviş Mustafa Baba vardır. Bu zat 1758'de bir vakıf kurmuş ve Bektaşi zaviyesini yaptırmıştır kendisi de 1779'daki vefatına kadar zaviyenin başında kalmıştır. ${ }^{122}$ Her ne kadar kabristanında mezar taşı bulunan es-Seyyid Mehmed Ali Baba kurucusu kabul edilerek birçok tekkenin rivayetlerinde görüldüğü gibi kurucu şeyhin kimliği İstanbul'un fethi ile ilişkilendirilmişse de tekkenin vakfiyeli bir zaviye olarak resmi kayıtlara geçirilmesi Bosnevi Derviş Mustafa Baba ile olmuştur. Zaviye iki taraftan Müslüman mezarlığı, bir taraftan Velizade Efendi bahçesi ve bir taraftan da yol ile çevrelenmiş bir oda ve ahırdan oluşan ve etrafı taş duvarlı bir mekan olarak vakfiyede tarif edilmiştir. ${ }^{123}$ Zeynep Hatun mahallesinde bulunmaktadır. Kendisinden sonra oğlu Derviş bin Fuzuli bin Muhammed şeyh olmuştur. ${ }^{124}$

Karyağdı Baba tekkesi Yeniçeri Ocağı’nın kaldırılması ile yıktırılmışır. Meydan odasının bulunduğu mahal tamamen yıkılmış kiremit kaplı türbesine dokunulmamıştır. Tekke bu tarih itibarıyla 1300 zirâ (yaklaşık 1 dönüm, $797 \mathrm{~m}^{2}$ ) bahçeye sahiptir. ${ }^{125}$ Sultan Abdülmecid (1839-1861) döneminde Nakşibendi tekkesi olarak tekrardan açılmış fakat gizli olarak Bektaşi ayinleri yapılmaya devam etmiştir. Tekkenin tekrardan canlandırılmasında 1876'da vefat etmiş olan Mehmed Necib Baba'nın rolü büyüktür. Kendisinin tekke matbaasında basılmış 20 sayfalık küçük bir risalesi bulunmaktadır. ${ }^{126}$

\section{Kıncı Baba Tekkesi}

Kıncı Baba tekkesi hakkında literatürde çok fazla bilgi kayda geçmemiş olmakla beraber tekrarlanan sabit bir bilgi vardır. Üsküdar'da Nuh kuyusu civarında

120 Nicolas Vatin ve Thierry Zarcone, "Un tekke bektachi d'İstanbul: Le tekke de Karyagdı," der. Alexandre Popovic ve Gilles Veinstein, Bectachiyya: Études sur l'ordre myst'que des Bektach's et les groupes relevant de Hadj' Bektach içinde (İstanbul: ISIS, 1995), s. 222-23. 121 Işın, "Bektaşilik," s. 134.

122 Nicolas Vatin ve Thierry Zarcone, "Le tekke de Karyagdı," s. 224.

123 Zarcone, "Karyagdi”, s. 230-31.

124 BOA, C.EV. 477, no. 24138 (1193/1779).

125 BOA, MAD 9371, no. 406 (1242/1826).

126 Nicolas Vatin ve Thierry Zarcone, "Le tekke de Karyagdı,” s. 226. 
bulunan bu tekke Yeniçeri Ocağı kaldırılışı esnasında yerle bir olmuş, şeyhi idam edilmiştir. Bunun nedeni olarak da Ocakla yakın ilişki gösterilir.

Kıncı Baba Tekkesi, Feyzullah Baba b. İsmail b. el-Hac Mehmed Efendi tarafından kurulmuş, vakfiyesi 1217/1803 senesinde hazırlanmıştır. Yani kuruluşu ve yıkılması arasında sadece 26 yıl bulunmaktadır. Feyzullah Baba b. İsmail 287 zirâ arsa üzerinde bulunan menzilini bu tekkeye vakfetmiştir. Arazi Arakiyyeci el-Hac Mehmed mahallesindedir. Etrafında zaviyenin bahçesi, Mustafa Bey adl bir şahsın mülkü, bir ana yol, ve İsmail Efendi adlı bir zata ait olan Nakşibendi türbesi ile çevrildiği vakfiyede belirtilir. Vakfedilen menzil Feyzullah Babanın kendi yaşadığı bahçe içinde bir konut olup fevkani 2 oda, bir sofa ve tuvaletten ibarettir. İçinde içme suyu da bulunan bir bahçesi vardır. Ancak vakfedilen sadece şeyhin menzilidir, zaviye ve bahçe eklendiğinde tekkenin ne kadar büyüklükte bir araziye oturduğunu bilemiyoruz. Gene tekkenin bu tarihten daha önce kurulmuş olduğunu düşünmek mümkündür, zira zaviye vakfiye düzenlenirken mevcuttur.

Vakfiyeye göre, Feyzullah Baba kendisi öldükten sonra el-Hac Mehmed Şarcı Baba'nın yerine geçmesini hem mülkünde oturup hem de tekkeyi yönetmesini şart koşmuştur. Mehmed Şarcı Baba’nın vefatıyla da derviş Salih bin Hasan'ın şeyhliğe geçmesi de şartlar arasındadır. ${ }^{127}$ Fakat Feyzullah Babanın vefatıyla Salih Dede zaviyedarlığa atanır. Bunun üzerine açılan bir davada Salih Baba’nın tarikattan ihraç gerektiren kusuru olduğunu, vakfiyeye uyulmadığını ve aslen el-Hac Mehmed Şarcı Baba’nın bu mevkide olması gerektiği kesinleştirilir. ${ }^{128} \mathrm{Bu}$ şeyhliğe kimin geçeceği kavgası içerisinde olayı daha da karmaşık hale getiren husus kurucu şeyh Feyzullah Baba'nın öldürülmüş olmasıdır. ${ }^{129}$

Yeniçeri Ocağı'nın kapatılması esnasında Feyzullah Babadan sonra gelen şeyhi idam edilmiştir, ancak tekkenin kapatılmadığı anlaşılmaktadır. Kapatılma esnasında ise şeyhin evinin bulunduğu arsa 287 zirâ olarak belirtilmiş bunun hulefasına vakfedildiği belirtilmiştir. Yıkılan tekkenin bulunduğu bölüm ise 50 zirâ arsa üzerindedir. ${ }^{130}$ Tekkenin arazileri 7 Şaban 1280/1863 yılında el-Hac Hasan Efendi bin el-Hac Mehmed Sadık adında bir Üsküdarlıya satılmıştır. Belgeye göre tekkeye ait araziler 1006 zirâ (yaklaşık yarım dönüm $614 \mathrm{~m}^{2}$ ) olup 6300 kuruşa alınmıştır. ${ }^{131}$

127 VGM 744-11-298-89 (7 Zilkade 1217/ 1 Mart 1803); VGM 744-11-298-90 (1217/1803). 128 VGM 777-6 (1223/1808). Salih Baba 1227/1812 yılında tekkeden ihraç edilir. Bkz. BOA, EV.MKT 1177, no. 199.

129 BOA, CE.ADL 1824 (1241/1825).

130 BOA, MAD 9731 (1242/1826).

131 BOA, EV.MKT 1305-393 (1298/1881). 


\section{Tahir Baba Tekkesi}

El-Hac Mehmet Tahir Baba bin Ali tarafindan 1213/1798 yılında kurulmuş olan Bektaşi tekkesi Üsküdar'da Çamlıca-i kebir'de bulunan Kısıklı karyesindedir. ${ }^{132}$ Fakat vakfiyenin tescilinin yapıldığ 1 1234/1819 senesinde bu bölge Kefeci mahallesi olarak belirtilmiştir. ${ }^{133}$ Kuruluşunda atanmış olan mütevellisi es-Seyyid Mehmed Said Ağa bin Hüseyin'dir. Vakfiyesine göre Sultan II. Abdülhamid vakfi mülhakatından merhum Bostancıbaşı Abdullah Ağa vakfına 120 akçe mukataa ile temessük verilmiş olan arazi Tahir Baba’nın tasarrufuna verilmiştir.

Bahsedilen arsa 12 dönümdür. Arsa üzerinde bir tevhidhane, iki hücre ve onların üstünde bir diğer hücre, mutfak, kiler, ahır, iki kenif, bir su kaynağı, meyve veren ve vermeyen ağaçlar, üzüm bağları ve sokak kapısına bitişik bir zaviyeden oluşan oldukça büyük bir kompleks yapıdır. Vakfiyenin tescil edildiği 1234/1819 senesinde ise tüm bu mülk sayılmasa da ek olarak bir de şirahaneden bahsedilmektedir. ${ }^{134} 12$ dönümlük bu kompleksin 19 . yüzyılda açılmış olması oldukça çarpıcıdır. Bu dönemde açılmış diğer tekkelere baktığımızda Karyağdı Baba tekkesinin yaklaşık bir dönüm, Kıncı Baba tekkesinin ise yaklaşık yarım dönüm kadar bir araziye yerleşmiş olduklarını görüyoruz. Kadim tekkelerden Karaağaç tekkesi dahi -ki bu tekkenin Yeniçeri Ocağının şeyhini çıkartıyor olması gibi özel bir statüsü de vard1- sadece 10 dönüm bir arazidedir.

Tahir Baba tevliyeti yani vakfın idaresini kendisine şart koşmuş ölümünden sonra ise tevliyetin zevcesi Emine Hatun ibneti el-Hac Mustafa'ya geçmesini ve zaviyede yaşamaya devam etmesini şart koşmuştur. Meşihatin evladlarına geçmesini ve eşinin vefatıyla tevliyetin de şeyh olan evlada verileceğini ilan eder. Tevliyeti devam ettirecek evladı kalmadığında da vakfın tevliyetinin Sultan II. Abdülhamid vakfına geçmesini belirtir. Vakfın yönetimi Sultan II. Abdülhamid vakfına geçtiğinde meşihatin gene zaviye halifelerinde devam etmesini ve buna müdahalede bulunulmamasını şart koşar. Vakfın şartlarından bir diğeri de tevliyet ve meşihatının bahsi geçen Bostancıbaşı Abdullah Ağa’nın denetiminde olmasıdır. Her türlü atamanın ancak Ağa’nın arzı ile yapılabileceği şart koşulmuştur. 19. yüzyıla gelindiğinde böyle büyük bir Bektaşi zaviyesi vakfının selatin vakıflarından alınmış arazi üzerine ve bir Bostancıbaşı nezaretinde kurulması son derece dikkat çekicidir.

132 VGM 744-85-22 (1213/1799).

133 BOA, evkaf müfettişliği 340, no. 162 (1234).

134 BOA, evkaf müfettişliği 340, no. 162 (1234). 
Tahir Baba’nın tekkeye vakfettiği mülk, üç odalı, iki katlı bir konaktır. Yeniçeri Ocağı’nın kaldırılışında binaları yıkılmış, şeyhi sürülmüştür. 1826'dan sonra Nuri Baba tekkesi adı altında devam etmiş, şeyhleri Ali Nutki Efendi (1869-1936) ve oğlu Nuri Baba olmuştur. Yakub Kadri Karaosmanoğlu’nun Nur Baba romanında bahsi geçen Bektaşi tekkesinin şeyhi Nur Babanın bu tekkenin şeyhi olan Nuri Baba olduğu ileri sürülmüştür. ${ }^{135}$

\section{Sonuç Yerine}

Bektaşilikle Yeniçeri Ocağı yukarıda bahsettiğimiz verilerden yola çıkarak söylenebilir ki bir kader birliği belki de Ocağ ın kuruluşundan itibaren başlamış fakat hem Bektaşi tarikatının kurumsallaşma süreci hem de Ocağ’ in yüzyıllar içerisindeki değişimi ile ilişkileri sürekli evrilmiştir. Ne Ocak aynı kalmıştır bu uzun zaman diliminde, ne de Bektaşilik. Bu konunun, Yeniçeri Ocağı'nın içerisindeki değişimler ve şehir hayatına karışması ile beraber ele alınarak daha ayrıntılı incelenmesi gerekir. Bu makalede amaç İstanbul'daki Bektaşi tekkelerinin 1826'daki kapanışlarına kadar ki tarihçelerine bir katkı sağlamaktır. Fakat bu eksende dahi Yeniçeri Ocağı'ndan bağımsız bir şekilde tekkeleri tartışmak mümkün değildir.

Altı çizilmesi gereken iki unsur vardır. Birincisi, II. Bayezid döneminde Bektaşi tarikatının merkezi bir sistemle örgütlenmesi sadece Balım Sultan'ın Dimetoka'dan Kırşehir'deki Hacı Bektaş Veli tekkesinin şeyhliğine getirilmesiyle değil İstanbul'daki tekkelerin de Bektaşi tarikatını temsilen kurulmaya başlamasıyla bir bütünlük arz eder. Bu iki aşama birbirinden bağımsız olmadığı gibi, İstanbul'un fethinden hemen sonra değil, II. Bayezid döneminde tarikatlara verilen devlet teşviki ve daha önemlisi üst denetim mekanizmalarının oluşturulması amacıyla İstanbul'da konuşlandırılmalarından bağımsız değildir. Tarikatların İstanbul'da temsili başta Halveti, Bayrami ve Nakşibendilerin tekkeler kurmasıyla başlamış daha sonra Bektaşilerin de bu şehirde kurumsal bir yapıya kavuşturulduğu görülmüştür.

İkinci unsur ise, İstanbul'daki Bektaşi tekkelerinin kuruluş süreci değerlendirilirken Yeniçeri Ocağı ile temaslarının ne olduğu sorusu mutlaka ele alınmalıdır.

135 Roman hakkında bilgi ve döneminde almış olduğu eleştiriler için bkz. Server Tanilli, "Le Roman Nur Baba de Yakub Kadri Karaosmanoğlu (1921-22) el la réalité du Bektachisme," der. Alexandre Popovic ve Gilles Veinstein, Bectachiyya: Études sur l'ordre myst'que des Bektach's et les groupes relevant de Hadj' Bektach içinde (İstanbul: ISIS, 1995), s. 185-190. 
Görülmektedir ki tekkeler hem askeri önem arz eden yerlere kurulmaları, hem de yeniçerilerin yoğun olduğu bölgelere konuşlanmış olmaları ile bize bu ilişkinin varlığını işaret etmektedirler. Bunun yanı sıra tam olarak tarihini bilmemekle beraber, muhtemelen II. Bayezid ile başlamış olan süreçte Yeniçeri Ağası'nın Kırşehir'deki merkez tekke üzerinde resmi bir yetkiyle donatılmasının bu merkez teşkilatlanmasını tamamlayan bir aşama olarak değerlendirilmesi gerekir. Bu tekkenin şeyh atamalarının ancak Yeniçeri Ağası'nın arzı ile yapılabildiğini arşiv belgelerinde tespit etmiş bulunuyoruz.

Bektaşi tekkelerinin kuruluşu ekseninde ortaya çımış bir diğer tema ise kuruluşlarının İstanbul'un fethi zamanına dayandırılmasıdır. Birçoğunun kuruluş tarihini bilmediğimiz tekkelerin sözlü geleneklerinde İstanbul'un fethinde bulunmuş bir abdal veya eren kurucu şeyh olarak kabul edilmektedir. Bu icad edilmiş bir gelenektir. Bu araştırmamızda bazı tekkelerin kuruluş tarihlerini, bazılarının kurulmuş olabileceği dönemleri saptamış bulunmaktayız.

Karaağaç, Mehmed Efendi ve Şehidlik tekkelerinin 1826'da kapatılmaları esnasında yapılan muamelede II. Bayezid vakfı tarafindan zapt edildikleri baz alınarak bu dönem içerisinde kurulmuş olabilecekleri öne sürülmüştür. Bu olasılığı destekleyen tarihsel bağlam makale içerisinde değerlendirilmiştir. II. Bayezid zamanında Halvetilik, Bayramilik ve Nakşibendiliğin de aynı şekilde devlet teşviki ile İstanbul'da tekkeler kurması, II. Bayezid'in Bektaşi tarikatını Kırşehir merkezli bir teşkilatlanmaya teşvik etmesi bu belgenin anlamını derinleştirecek tarihsel altyapıyı bize sunmaktadır.

Karaca Ahmed Sultan türbesinin Gülfem Hatun (ö. 1561) tarafından yaptırılmış olması ve tekkenin Atik Valide Sultan vakfına (vakfiyesi 1582) ait olarak belgelerde kayıt edilmesi bize 16. yüzyılın ikinci yarısına denk gelen bir dönemde kurulduğunu düşündürmektedir. Yarımca Baba tekkesi vakfının kuruluş tarihi 1617-18 olarak belgelerde tespit edilmiştir.

Karyağdı Baba tekkesinin sözlü geleneği kuruluşunu İstanbul'un fethine dayandırmasına rağmen Bosnevi Derviş Mustafa Baba’nın 1758'de kurduğu vakıf ile bu Bektaşi zaviyesini yaptırdığını ve kendisinin de 1779 'daki vefatına kadar zaviyenin başında kaldığını Nicolas Vatin ve Thierry Zarcone'un çalışmalarından öğreniyoruz.

18. yüzyıl sonu-19. yüzyıl başlarında kurulmuş olan 3 büyük Bektaşi tekkesi bulunmaktadır: Karyağdı Baba tekkesi, Kıncı Baba ve Tahir Baba tekkeleridir. Vakıflar Genel Müdürlüğü Arşivinde tespit edebildiğimiz vakfiyesinden Kıncı 
Baba tekkesinin Feyzullah Baba b. İsmail tarafindan 1800 senesinde kurulmuş olduğunu anlıyoruz. Feyzullah Baba’nın öldürülmüş olması ve peşinden makamına gelecek kişiler arasında çatışma yaşanması bize tekkenin siyasi ve idari profilinin sorunlu olduğunu düşündürmektedir. Kuruluşundan sadece 26 sene sonra Yeniçeri Ocağı'nın kaldırılmasıyla yıkılmış bir tekkedir. Şeyhi ise idam edilmiştir.

Siyasi profili üzerinde düşünülmesi gereken bir diğer tekke ise Tahir Baba tekkesidir. Vakfiyesine göre Sultan II. Abdülhamid vakfından Bostancıbaşı Abdullah Ağa vakfına devredilen arazi, ağa tarafından Tahir Baba’ya verilmiştir ki 12 dönümlük bir arazidir. Karaağaç tekkesi dahi yaklaşık 10 dönümlük bir araziye sahiptir. Yüz ölçümü bilinen tekkeler arasında en büyügü 88 dönümlük bağ ve bahçelerden oluşan arazisi ile Şehidlik tekkesidir -ki bu bağ ve bahçelerin tekkeye ne zaman eklendiği tam bilinmemektedir. Oysa bu kadim tekkeler haricinde kendisiyle yakın dönemde kurulmuş olan Kıncı Baba tekkesinin arazisi sadece yarım dönüm, Karyağdı Baba tekkesi ise 1 dönümdür. Böyle büyük bir arsanın Bostancıbaşı tarafından bağışlanması ne anlama gelmektedir? 1798'de kurulmuş bu tekke vakfiyesinde Bostancıbaşı'nın arzı ve onayı ekseninde hareket edeceğini kabul etmiştir. Acaba bu siyasi korumanın 1826'da kaderini tayin etmesinde etkisi olmuş mudur?

İstanbul'daki Bektaşi tekkeleri hakkında cevaplanması gereken daha birçok soru vardır. Sanıyorum bunlardan bir tanesi niçin 1826'ya ramak kala 3 büyük tekkenin kurulduğudur. II. Mahmud'un Yeniçeri Ocağını kaldırdığını ilan ettiği fermanında Bektaşilerle olan ilgilerine değinilmiş ve şu ifade kullanılmıştır: '. . . bir müddetten berü Bektâşî gürûhı Yeniçeri tâifesine istinâd ile o misillü tekyeler ve zevâyânın isimlerini tahrîf ve kendilerine nisbet ile zabt ve hâsılât-ı vakfı nefslerine hasr ve fisk u fücûr ile ekl ü bel' ve ba'zı mahallerde dahi halkı idlâl içün müceddeden tekyeler ihdâs ve birer fâsid vakfiye tertîbiyle ihtira'-1 evkaf iderek sırran ve alenen envâ-1 şenâ‘ate cesâret itmekde oldukları tahkik-gerde-i mülûkânem olan hâlâttan ve bî tevfikihî te'ala devlet-i aliyye-i ebed-rehînim esâs-1 şerî́at-1 mutahhara ile müesses ve müşeyyed oldığına binâen zat-1 melekiyyü’s-sıfât-ı mülûkânem her hâlde habl-i metîn-i şer'-i şerîfe tevessül ve temessük iderek.... ${ }^{136}$ Fermanda iktidarı rahatsız eden hususun Bektaşi-Yeniçeri ilişkisinin vakıflar düzeyinde olduğu vurgulanmaktadır. Yeniçerilere destek veren Bektaşi gruplarının bunu direkt olarak vakıflar kurup tekkelerinde halkı Yeniçeriler lehine etkilemek suretiyle gerçekleştirdiği iddia edilmektedir. Yukarıda bahsi geçen belge, Yeniçerilerin Bektaşi 
tekke vakıfları kurmada etkinliğini 'bir süreden beri' şeklinde nitelemiş olmakla beraber bu sürenin adı başka arşiv belgelerinde konmuştur. Yeniçeri Ocağı'nın kaldırılması esnasında düzenlenmiş bir hatt-1 hümayun Eyüp, Üsküdar, ve Boğaziçi taraflarında tekkeler kurmuş olan Bektaşi taifesinin halkı idlal etmekte olmalarından dolayı, son 60 senede açılmış olan tekkelerin Nakşibendi tekkesi yapılmasını buyurmaktadır. ${ }^{137}$ Bu süre bizim Bektaşi tekkelerinin sayısındaki artışı gözlemlediğimiz süre ile paraleldir. Bu dönem içerisinde Bektaşilerin İstanbul'da yeni bir yapılanmaya gitmiş olduklarını düşünmek doğru görünüyor.

Son olarak analiz edilmesi gereken unsur ise Nakşibendi tekkesine dönüştürülen tekkelerin gerçekten sadece son 60 yılda kurulmuş olup olmadığıdır. Bizzat Kırşehir'deki Hacı Bektaş Veli tekkesinin ve en büyük Bektaşi tekkelerinden Antalya Elmalı'daki Abdal Musa tekkesinin başına Nakşibendilerin yerleştirildiğini biliyoruz. ${ }^{138}$ Dolayısıyla, son 60 yıllık sürede kurulmuş Bektaşi tekkelerinin bozulmuş olduğu iddiası, Bektaşilere karşı alınmış şiddetli kararı meşrulaştırmak için ortaya atılmış bir siyasi argüman olarak alınmalıdır. Bizzat devlet yetkilileri kapatılma işlemlerinde bu kriteri baz alarak hareket etmemişlerdir. Burada düşünülmesi gereken Yeniçeri Ocağı'nın kapatılması esnasında sadece yeniçerilerin muhalefetini değil, ocakla ilişkili veya muhalif duran her kesimi susturmak ve kontrol altına almak gayesinin ön plana çıktığıdır.

İstanbul'daki Bektaşi tekkeleri, II. Bayezid döneminde şehrin dini kültürel yapılanmasında ortaya çıkmış ve bir yüzyıl boyunca bu oluşum devam etmiştir. Bu esnada İstanbul'daki tekkeler hem merkez olan Kırşehir'deki Bektaşi tekkesi ile, hem de Yeniçeri Ocağı ile kurumsal bağlar kurulmuştur. Tekkeler bu yapı içerisinde 19. yüzyıla kadar gelmiş, yüzyılın başında yeni açılan önemli tekkeler ile bir canlılık yaşamış, fakat bu yeni gelişim süreci 1826 'da yeniçeriliğin kaldırılması esnasında devletin sert müdahalesi ile durdurulmuştur.

137 BOA, HAT 290: 17351, ( 1242/1826)

138 Ayar, Bektaşilikte Son Nefes, 59-60; Abdal Musa Tekkesine Nakşibendi şeyhlerin yerleştirilmesi sonucu bölge halkı ve şeyhler arasında çıkan sorunlar hakkında daha fazla bilgi için bkz. Hatice Durgun, "XIX. yy.'da Elmalı Abdal Musa Dergahı Şeyhliği ve Vakıflarına Yönelik Müdahaleler,” Adalya 17 (2014), s. 295-311. 
Öz — Bu makale İstanbul'daki Bektaşi tekkelerini şehrin fethinden tekkelerin 1826'da Yeniçeri Ocağı'nın kaldırılmasıyla birlikte kapatılması/dönüştürülmesi/daha sıkı denetim altına alınmasına kadar ki süre zarfında incelemiştir. Çalışmanın amacı İstanbul'un Bektaşi tekkelerinin tarihini Bektaşiliğin ve Yeniçeri Ocağı'nın kurumsallaşma süreçleri ekseninde değerlendirip bu tarihin bağlamsal bir analizini yapmaktır. Çalışmada II. Bayezid döneminde devlet yönetimi altında teşkilatlanan Bektaşiliğin İstanbul tekkelerinde de benzer bir kurumsallaşmaya gittiği tezi savunulmuştur. Makale özellikle tekkelerin kuruldukları dönemlere yoğunlaşarak bu tezi geliştirmeye çalışmıştır. Tarihsel sürecin ikinci evrilme noktası ise 18. yüzyılın ikinci yarısıdır. İstanbul'daki önemli bazı tekkeler bu dönemde kurulmuş; 1826 müdahalesi ile girdikleri yeni süreç sekteye uğratılmıştır. Makalenin bir diğer amacı İstanbul'da bahsi geçen zaman içerisinde kurulmuş tüm tekkeleri incelemek ve coğrafi konumlarından ekonomik yapılarına bir çok konuda tarihsel gelişimlerini belgeler ışığında anlatmaktır.

Anahtar kelimeler: Bektaşilik, Tekke, İstanbul, II. Bayezid, Yeniçeri Ocağı, Vakfiye, Karaağaç, Erikli Baba, Perişan Baba, Şehidlik, Durmuş Dede, Şahkulu Sultan, Karaca Ahmed Sultan, Yarımca Baba, Mürüvvet Baba, Karyağdı Baba, Kıncı Baba, Tahir Baba, İstanbul'un Fethi

\section{Kaynakça}

Başbakanlık Arşivi

Cevdet-i Evkaf, (C.ev.) 137, 468, 473, 477, 493, 509, 627

Cevdet-i Zabitiye (C.zb) 34, 2282

Cevdet-i Adliye (C.adl) 1824

Evkaf Defterleri (Ev.d) 38565

Evkaf Muhasebe Kalemi (Ev. mh) 64, 644, 748, 2084, 2409

Evkaf Mektubi Kalemi (Ev.mkt) 120, 782, 1177, 1305, 2201, 3182

Evkaf Cihat Kalemi (Ev.mkt.cht) 402, 455, 598, 697

Evkaf Evamir (Ev.mkt.evm) 38, 123, 127, 132

Evkaf Müfettişliği 340

Evkaf Tahrirat (Ev.thr) 129

Evkaf Başkitabet (Ev.bkb) 106

Kamil Kepeci (KK) 6599

İbnül Emin Evkaf (İE) 5707

Hattı Hümayun (HAT) 293 
Maliyeden Müdevver (MAD) 9731

Vakıflar Genel Müdürlüğü Arşivi 46, 438, 577,744, 777, 887, 892, 2381

\section{Basılmış Birincil Kaynaklar}

Ayvansarayi Hüseyin Efendi, Hadikatül-Cevami, 2 cilt. İstanbul: Matbaa-i Amire, 1281.

Hünkar Hacı Bektaş Veli Velayetnamesi, der. Hamiye Duran ve Dursun Gümüşoğlu. Ankara: Gazi Üniversitesi Türk Kültürü ve Hacı Bektaş Veli Araştırma Merkezi, 2010.

Çelebi, Evliya. Evliya Çelebi Seyahatnamesi: Topkapı Sarayı Bağdat 304 Yazmasının Transkripsiyonu-Dizini, derleyen Zekeriya Kurşun, Seyit Ali Kahraman, Yücel Dağlı, cilt 1. İstanbul: Yapı Kredi Yayınları, 1999.

\section{İkincil Kaynaklar}

Azamat, Nihat: "İdrîs-i Muhtefî”, DİA, 21 (2000): 489-91.

Bacqué-Grammont, Jean-Louis: "Contribution à l'étude des cimetières: Note sur la typologie des steles.” Anatolia Moderna II (1991): 42-48.

Bacqué-Grammont, Jean-Louis, H.P Laqueur ve Nicolas Vatin: “Corpus de Stalae Turcicae V”, Anatolia Moderna II (1991): 92-136.

Barkan, Ömer L.: "Osmanlı İmparatorluğunda bir İskan ve Kolonizasyon Metodu Olarak Vakıflar ve Temlikler”, Vakıflar Dergisi, 5 (1942): 279-386.

Barkan, Ömer L. ve Ekrem Hakkı Ayverdi: İstanbul Vakıfları Tahrir Defteri 953 (1546) Tarihli, İstanbul: Baha Matbaası, 1970.

Birge, John Kingsley: The Bektashi Order of Dervishes. London: Luzac Oriental, 1994.

Canatar, Mehmet: İstanbul Vakıflar Tahrir Defteri: 1009 (1600) Tarihli, İstanbul: İstanbul Fetih Cemiyeti, 2004.

Clayer, Natalie ve Nicolas Vatin: "Un établissement de derviches Stambouliote: Le tekke d'İmrahor”, Anatolia Moderna-Yeni Anadolu VI (1996): 31-81.

Çamuroğlu, Reha: Yeniçerilerin Bektaşiliği ve Vaka-i Şeriyyesi, İstanbul: Ant Yayınları, 1991.

Çetin, Atilla: “İstanbul'daki Tekke, Zaviye ve Hankahlar Hakkında 1199/1784 Tarihli Önemli Bir Vesika”, Vakıflar Dergisi XIII (1981): 583-590.

Dumont, Paul ve Béatrice Saint Laurent: “Le complexe du tekke Bektaşi de Merdivenköy”, Anatolia Moderna, II (1991): 75-91.

Durgun, Hatice: "XIX. yy.'da Elmalı Abdal Musa Dergahı Şeyhliği ve Vakıflarına Yönelik Müdahaleler”, Adalya, 17 (2014): 295-311.

Düzbakar, Ömer: "Charitable Women and Their Pious Foundations in the Ottoman Empire: The Hospital of the Senior Mother, Nurbanu Valide Sultan”, JISHIM 5 (2006): 11-20. 
Eldem, Edhem: Death in Istanbul: Death and Its Ritual in Ottoman-Islamic Culture, İstanbul: Ottoman Bank Archives and Research Centre, 2005.

Emecen, Feridun: Fetih ve Kiyamet 1453, İstanbul: Timaş Yayınları, 2012.

Ergin, Nina: "Taking Care of Imarets: Repairs and Renovations to the Atik Valide Imareti Istanbul, circa 1600-1700", derleyen Nina Ergin, Christoph K. Neumann, Amy Singer, Feeding People, Feeding Power: Imarets in the Ottoman Empire içinde, 151-167. İstanbul: Eren Yayınları, 2007.

Faroqhi, Suraiya: "Bektashis: Report on Current Research", derleyen Alexandre Popovic ve Gilles Veinstein, Bectachiyya: Études sur l'ordre myst'que des Bektach's et les groupes relevant de Hadj' Bektach içinde. 9-31. İstanbul: ISIS, 1995.

....... "The Tekke of Hacı Bektaş: Social Position and Economic Activities", IJMES 7 (1976): 183-208.

, "Einflusskämpfe, Strukturfragen und die stets problematische Rolle der Janitscharen: ein Beitrag zur Geschichte der Bektaschis vor 1826", Journal of Turkish Studies 26, no. 1 (2002): 215-227.

......, "Seyyid Gazi Revisited: The Foundation as Seen Through Sixteen and SeventeenthCentury Documents", Turcica 12 (1981): 90-122.

Garnett, Lucy Mary Jane: Osmanl Toplumunda Dervişler ve Abdallar, İstanbul: Dergâh Yayınları, 2010.

Haskan, Mehmet Nermi: Eyüp Tarihi. İstanbul: Türk Turing Turizm İşletmeciliği Vakfi Yayınları, 1993.

Hasluck, F. W.: Christianity and Islam under the Sultans, İstanbul: ISIS, 2000; ilk bask1 1929.

......, Anadolu ve Balkanlarda Bektaşilik, çeviren Yücel Demirel, İstanbul: Ant Yayınları, 1995).

Işın, Ekrem: "Bektaşilik", Dünden Bugüne İstanbul Ansiklopedisi, 2 (1994): 131-37. , "İstanbul'da Tarikat Kültürü ve Gündelik Hayat", Dergâh, 6, no. 63 (Mayıs, 1995): 13-15.

İnalcık, Halil: Osmanl İmparatorluğu, Klasik Çağ (1300-1600), İstanbul: Yapı Kredi Yayınları, 2013.

...... The Survey of İstanbul 1455: the text English translation analysis of the text, documents, İstanbul: Türkiye İş Bankası Kültür Yayınları, 2012.

......, "Otman Baba ve Fatih Sultan Mehmed", Doğu, 26 (2004): 11-31.

Karakaya-Stump, Ayfer: "Irak’taki Bektaşi Tekkeleri”, Belleten, LXXI, 261 (Ağustos 2007): 689-720.

Kayaalp-Aktan, Pinar: "The Endowment Deed of the Atik Valide Mosque Complex: A Textual Analysis", Feeding People, Feeding Power: Imarets in the Ottoman Empire içinde. 261-273, İstanbul: Eren Yayınları, 2007. 
Kiel, Machiel: "Durbalı Sultan Resurrected?: Some Remarks on Resent Developments Around the Bektashi Tekke of Durbalı Sultan near Pharsala-Thessaly/Durbalı Sultan Yeniden Ortaya mı Çıkıyor?: Tesali Yakınındaki Bektaşi Tekkesi Durbalı Sultan Civarındaki Son Gelişmeler Üzerine Bazı Açıklamalar”, Türk Kültürü ve Hacı Bektaş Veli Araştırma Dergisi, 52 (2009): 53-58.

Kocadağ, Burhan: Şahkulu Sultan Dergâhı ve İstanbul Bektaşi Tekkeleri, İstanbul: Can Yayınları, 1994.

Köprülü, Fuat: Türk Edebiyatında İlk Mutasavvıflar, Ankara: Diyanet İşleri Başkanlığı Yayınları, 1966.

"Mısır'da Bektaşilik", Türkiyat Mecmuası, VI (1939): 13-39.

Köse, Fatih: İstanbul Halveti Tekkeleri, İstanbul: Marmara İlahiyat Fakültesi Yayınları, 2012.

Kufralı, K.: "Molla İlahi ve Kendisinden Sonraki Nakşbendiyye Muhiti”, Türk Dili ve Edebiyatı Dergisi, III/1-2 (1949): 129-151.

Kut, Günay ve Edhem Eldem: Rumelihisarı Şehidlik Dergâhı Mezar Taşları, İstanbul: Boğaziçi Üniversitesi Yayınevi, 2010.

Küçükyalçın, Erdal: Turna’nın Kalbi: Yeniçeri Yoldaşlı̆̆ı ve Bektaşilik, İstanbul: Boğaziçi Üniversitesi Yayınları, 2010.

Lifchez, Raymond: "The Lodges of Istanbul”, derleyen Raymond Lifchez. The Dervish Lodge: Architecture, Art, and Sufism in Ottoman Turkey içinde, 73-130, Berkeley, Los Angeles, Oxford: University of California Press, 1992.

Mélikoff, İrène: “L’ordre des Bektaşi aprés 1826”, Turcica, XV (1993).

......, Hacı Bektaş Efsaneden Gerçeğe, İstanbul: Cumhuriyet Yayınları, 2010.

Ocak, Ahmet Yaşar: Babailer İsyanı: Aleviliğin Tarihsel Altyapısı, Anadolu'da İslâm-Türk Heterodoksisinin Teşekkülü, İstanbul: Dergâh Yayınları, 2000.

......, "Bektaşilik", İstanbul: Di், 5 (1992): 373-79.

, "Emirci Sultan ve Zaviyesi”, Tarih Enstitüsü Dergisi, 9 (1978): 129-208.

Sabırlı, Tijen: Vakfiyesi ve Muhasebe Kayıtları Işı̆̆̆nda Nurbanu Atik Valide Sultan Vakfı, yayınlanmamış Yüksek Lisans Tezi, İstanbul Üniversitesi, 2012.

Sakaoğlu, Necdet: "Bayezid II.”, Dünden Bugüne İstanbul Ansiklopedisi, 2 (1994): 83-87.

Tanman, Baha: "Le tekke Bektachi de Kazlıçeşme; II. Emplacement, Architecture et Décoration”, Anatolia Moderna- Yeni Anadolu, VII. (1997).

, "Perişan Baba Tekkesi”, Dünden Bugüne İstanbul Ansiklopedisi, 6. İstanbul: Tarih Vakfi Yayınları (1994): 242-43.

Tekindağ, Şehabeddin: “Beyazid II.'in Tahta Çıkışı Sırasında İstanbul'da Vukua Gelen Hâdiseler Üzerine Notlar”, Tarih Dergisi, X/14 (1959): 85-96. 
Turnalı, Bilgin ve Esin Yücel: "Ağlamı̧ Baba”, İstanbul Kültür ve Sanat Ansiklopedisi 1: 329-30.

Uzunçarşılı, İsmail Hakkı: Osmanlı Devleti Teşkilatında Kapıkulu Ocakları, 2 cilt, Ankara: Türk Tarih Kurumu Basımevi, 1943.

Vatin, Nicolas: l'Ordre de Saint-Jean-de Jérusalem, l'Empire ottoman et la Méditerranée orientale entre les deux sieges de Rhodes 1480-1522, Louvain, Paris: 1994.

Vatin, Nicolas ve Thierry Zarcone: "Le tekke bektachi de Kazlıçeşme: I. Étude Historique et épigrahique", Anatolia Moderna-Yeni Anadolu, VII. (1997): 79-109. "Un tekke bektachi d'İstanbul: Le tekke de Karyagdı", derleyen Alexandre Popovic ve Gilles Veinstein, Bectachiyya: Études sur l'ordre myst'que des Bektach's et les groupes relevant de Hadj' Bektach içinde, 215-269, İstanbul: ISIS, 1995.

Yaman, Mehmet: Büyük Türk Akıncss-Evliyası-Hekimi Karaca Abmed Sultan Hazretleri, İstanbul: Karaca Ahmed Sultan Türbesini Koruma Derneği Yayınları, 1989.

Yerasimos, Stefanos: Konstantiniyye ve Ayasofya Efsaneleri, çeviren Ş. Tekeli, İstanbul 1993.

Yıldırım, Riza: "Dervishes, Waqfs and Conquest: Notes on Early Ottoman Expansion in Thrace", derleyen Pascale Ghazaleh, Held in Trust: Waqf in the Islamic World içinde, 23-40, Kahire: Amerikan Üniversitesi Yayınları, 2011.

....... "Bektaşi-Alevi Geleneğine Göre Seyyid Ali Sultan", Türk Kültürü ve Hacı Bektaş Veli Arasstrma Dergisi, 53 (2010): 59-87.

, "Muhabbetten Tarikata: Bektaşi Tarikatı'nın Oluşum Sürecinde Kızıldeli'nin Rolü", Türk Kültürü ve Hacı Bektaş Veli Araşttrma Dergisi, 53 (2010): 153-190.

Yılmaz, Kamil: Aziz Mahmud Hüdayi ve Celvetiye Tarikatt, İstanbul: Marmara Üniversitesi, 1980.

Zarcone, Thierry: "Les couvents Bektachis d'Istanbul", derleyen Alexandre Popovic ve Gilles Veinstein, Bectachiyya: Études sur l'ordre myst'que des Bektach's et les groupes relevant de Hadj’ Bektach içinde, İstanbul: ISIS, 1995.

"Merdivenköy el la géographie bektachie de l'Empire ottoman", Anatolia Moderna, II (1991): 37-42. 